\title{
Chapter 4 \\ Eastern Neighbourhood: Territorial \\ Cooperation Implies a Common Energy \\ Strategy
}

\author{
Vladimir Kolossov and Lisa Van Well
}

\begin{abstract}
The chapter outlines the major stakes of this neighbourhood. The Baltic Sea case study gives an on-the-ground insight of the EU-Russia partnership's reality. It shows that Kaliningrad could be a stumbling block to or a touchstone of cooperation with Russia; that cross-border cooperation is a means to foster ties with Russia; that people mobility is a key issue in the relationship between the EU and its neighboursall neighbours. Last, it shows that intergovernmental institutions include Russia but not always as efficiently as it could. Another case-study focuses on the Black Sea. The chapter presents innovative research results on city twinning and diplomacy networks, so as to compare the relative influence of EU and Russia on this area. The third case study provides a territorial analysis of the Ukrainian crisis, and explains why the East of the country is taken in a jaws effect. In conclusion, the chapter insists on the role of territorial cooperation, and on the need for a genuine European energy policy because it is indispensable for a genuine partnership between the EU and Russia.
\end{abstract}

\subsection{Stakes}

The Eastern neighbourhood (Map 4.1) encompasses the territories from the Baltic area to the Black Sea, which are Russia, Belarus, Ukraine and Moldavia. Such a grouping is motivated by geographical reasons (various historical and cultural links between these countries, decisive issue of European energy supply security from Russia through Ukraine, etc.), by historical (USSR) and political reasons (the Eastern Partnership), and by practical reasons: the data system of these countries remains close due to their common Soviet past and in all countries two post-Soviet censuses have been already held which allows time comparisons. Russia is not a country of the ENP, but the EU-Russia Strategic Partnership is crucial for territorial integration of the Baltic area.

\footnotetext{
V. Kolossov ( $\triangle)$

Institute of Geography, Russian Academy of Sciences, Moscow, Russia

e-mail: vladimirkolossov@gmail.com

L. Van Well

Nordregio, Stockholm, Sweden

(C) The Author(s) 2016

P. Beckouche et al. (eds.), Atlas of Challenges and Opportunities in European

Neighbourhoods, DOI 10.1007/978-3-319-28521-4_4
} 


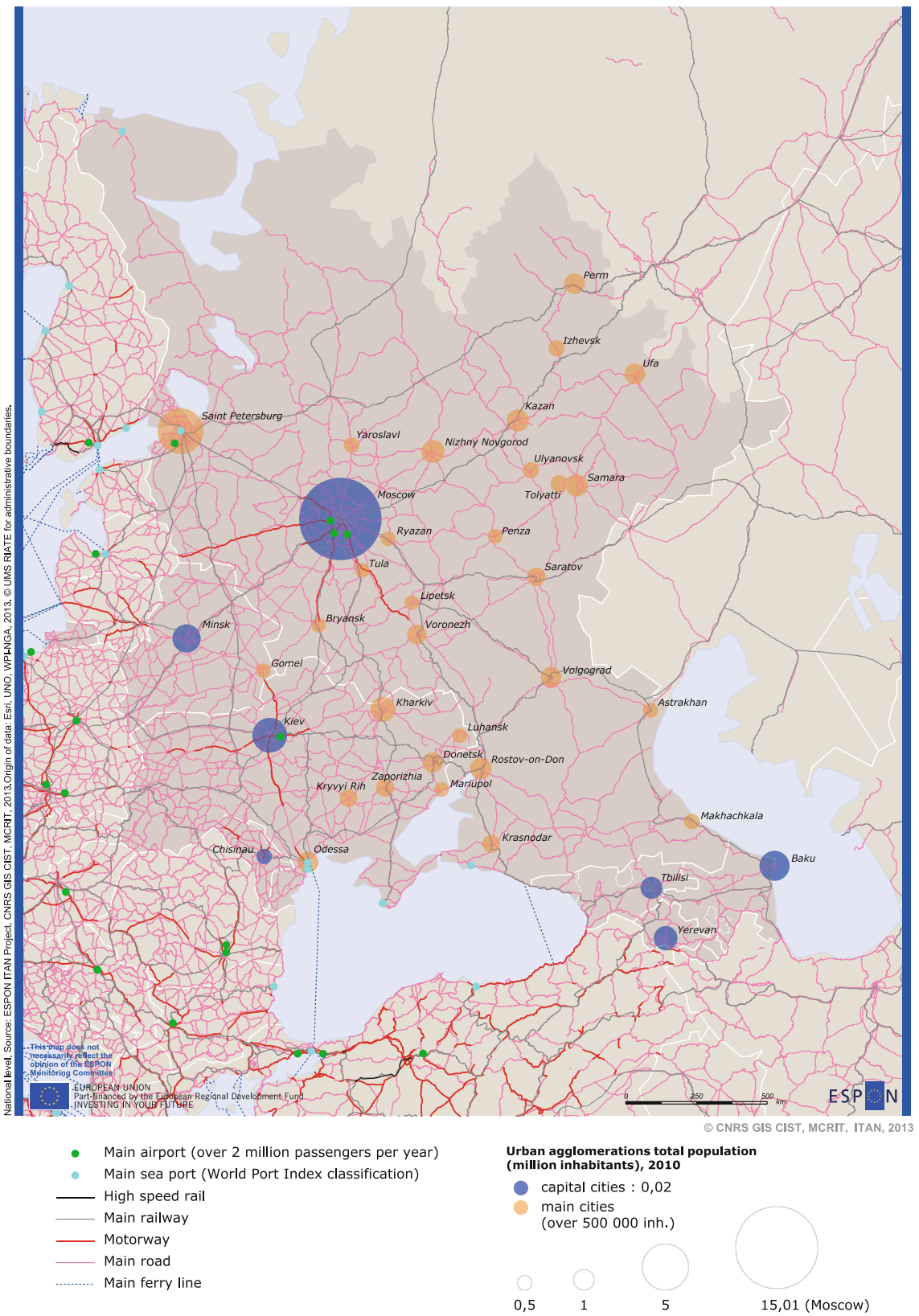

Map 4.1 The Eastern neighbourhood

Russia is the EU's biggest neighbour and the third biggest trading partner. It is an important supplier of oil and gas to the EU member states, in particular Central Europe countries. Deeper regional cooperation is essential for ensuring security and 
improving environmental and economic stability of the neighbourhood thanks to a better EU/Russia partnership. Among the issues is environmental deterioration of the Baltic Sea, climate change, trafficking in human beings, smuggling of harmful goods, communicable diseases, illegal immigration and organized crime. Moreover, through diminishing socio-economic imbalances and inequalities between the EU countries and western Russia, some of these challenges could be overcome, which would contribute to the overall stability of the area.

\subsubsection{Demographic}

The demographic decline is one of the major stakes of this neighbourhood. In January 2012 the population of Russia was 143 million, unevenly distributed across the country: $80 \%$ live in the European part of the country while $75 \%$ of its territory is located eastward of the Urals. Just after the collapse of the Soviet Union, in 1993, the population in Russia hit a historic peak at 149 million; then a 15 year long trend of population decline began. The main reasons were related to natural population decrease. In 1994-2009 the population in Russia decreased by 11.9 million due to natural change, but thanks to immigration surplus the total population decreased by "only" 6.7 million. Due to several major conflicts before 2002, in particular to theoften quite compelled-return of displaced people, Chechnya has a positive demographic trend during the last decade. But most of the regions do experience a loss in population. Population shrinkage mostly takes place in the most northern and eastern territories, as well as in the most rural regions. The regions located between St. Petersburg and Moscow suffer from the great attractiveness of these two metropolises. Russian regions along the border with Ukraine also experience a shrinking demographic trend.

In Ukraine and Belarus, nearly the entire country experiences negative demographic trends with the exception of the capital city. In Moldova, the entire country has declining population figures, mainly due to emigration to the EU, Russia and Turkey. Among the countries of the southern Caucasus, only Azerbaijan experiences a demographic growth despite strong out-migration.

Moscow dominates the neighbourhood with more than 11 million inhabitants, followed by St. Petersburg ( 5 million), Kiev ( 2.8 million) and Minsk (1.9 million).

The domestic migrants have their origins in the most rural and peripheral regions except when there is oil and/or gas. Domestic migrants in Belarus move from the provincial regions to Minsk. Internal migration is greater than external migration. In 2011 the annual migration turnover of those who moved permanently to another Russian region or city was 3.1 million, whereas the official (registered) international migration turnover was only 320,000. The most important destinations of migrants in Russia were Moscow, St. Petersburg and Krasnodar krai (by the Black sea), whereas the population of most subjects in the North, East Siberia and the Far East has decreased rapidly due to outmigration. After the collapse of the USSR, several shutdowns, degradations and relocations of industries and military activities took place. Also the fact that several support systems and privileges, such as the so-called 


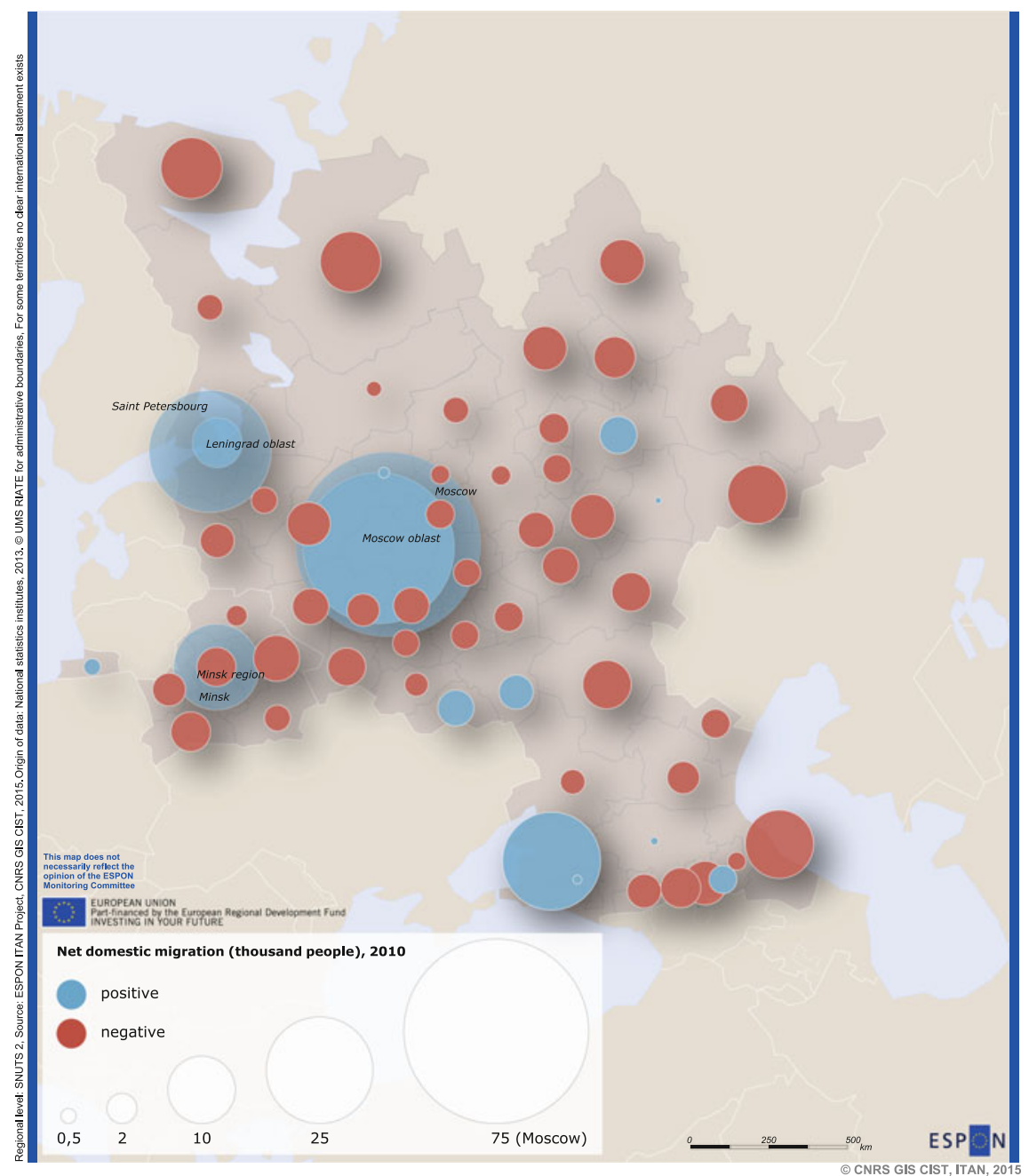

Map 4.2 Domestic migration in 2010

"northern wage increments"- extra money for working in remote regions with a harsh climate-were terminated had an impact as many people had taken advantage of these incentives to work in these regions temporarily for earning money (Map 4.2).

\subsubsection{Socio-economic}

In terms of gender balance, there is an urban-rural divide in Russia, Belarus and Ukraine with the capital regions (and St. Petersburg) having a more balanced 
number of males to females of working age. This is especially significant in Belarus where the Minsk metropolitan region stands out as more balanced compared to the surrounding region which has a lower number of females, perhaps due to the greater number of females moving to Minsk from the surrounding regions for employment or education. There is also a North-South divide, whereby the northernmost oblasts -Murmansk and Arkhangelskaya oblast-have fewer than 90 females per 100 males in working age. In Ingushetia republic in the North Caucasus, the female population of working age strongly dominates; among the reasons could be the high mortality rate of men of working age as a consequence of war-but some experts refer to mistakes made in population census....

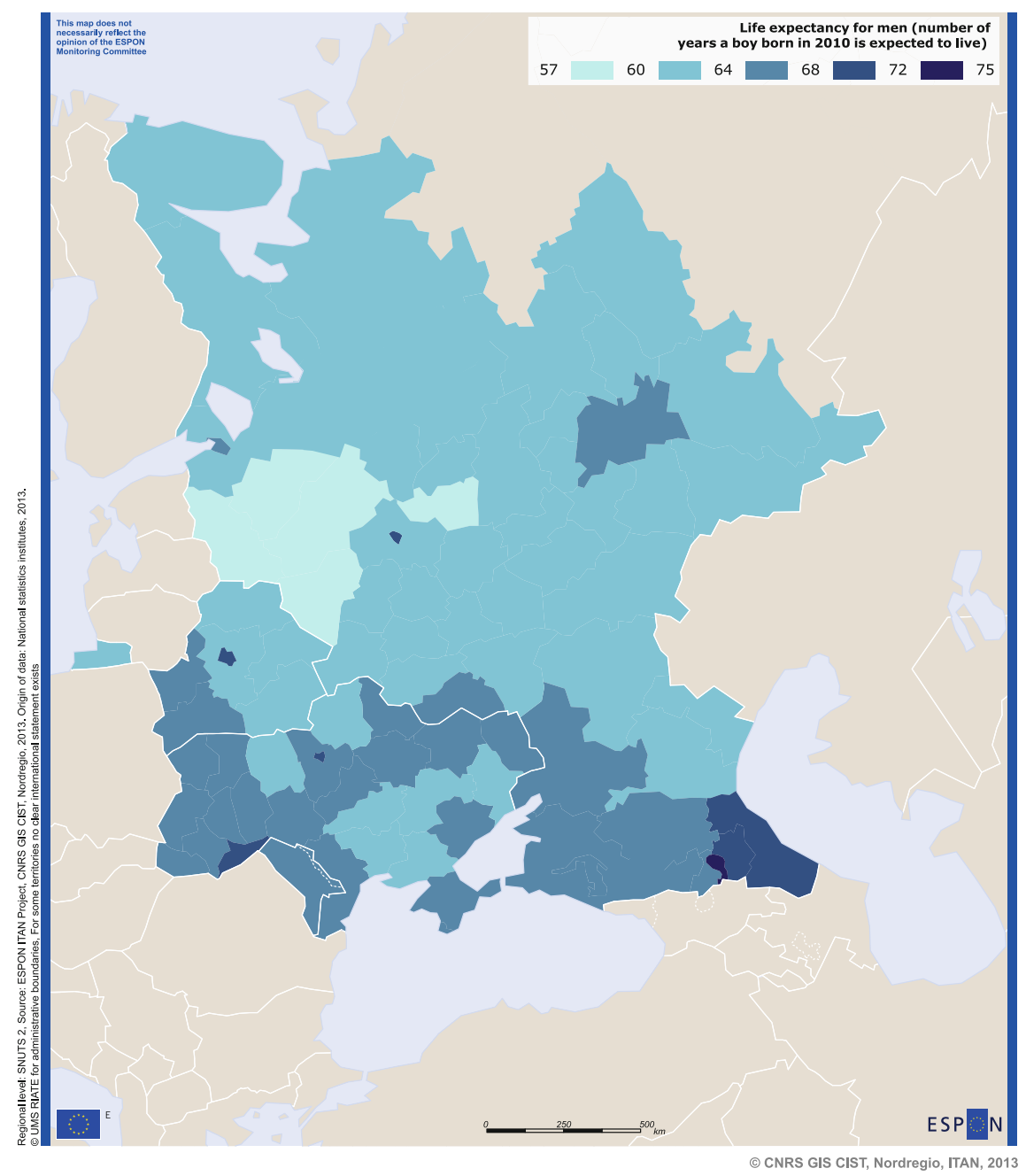

Map 4.3 Life expectancy for men, 2010 
Looking at the gender balance of all age groups in 2010 in total, one can notice a numeral superiority of females over males in the central regions of Russia, with the exception of Moscovskaya oblast. This could be a sign of a premature mortality among males (Map 4.3). Despite instability in North Caucasus, life expectancy for both genders is here the highest, in Ingushetia in particular. In this region with predominantly rural population, low level of education, strong religious and socio-cultural traditions there is a higher uncertainty about the mortality rates (Kvasha and Harjkova 2010). But higher life expectancy could be also attributed to a lower consumption of alcohol by the Muslim population residing here, as well as in the Republic of Tatarstan which also stands out in terms of longevity of both genders.

Life expectancy is somewhat higher in the capital cities (Moscow, Minsk and Kiev) and the St. Petersburg urban area due to a high number of jobs in the tertiary sector, highest income of the population, economic stability and a better access to high quality medical service. In many regions of Ukraine, life expectancy is higher than in Russia, particularly for men. Life expectancy is also higher in the Belorussian and Ukrainian regions on the EU border, especially when it comes to women.

The North Caucasus region (Chechnya and Dagestan) is characterised by a high fertility rate which can be explained by strong cultural and religious traditions, and a low level of education. At the same time there is a lower proportion of the elderly in these regions and a fairly low share of active population. Besides the North Caucasus there are only two oblasts in North-East Russia (Republic of Udmurtia and Republic of Bashkortostan) with a slightly higher share of children and young. The same goes for Moldova - a high proportion of children and young people, with a low proportion elderly and active population.

The Murmansk Oblast of Russia has the highest rate of active population while Belarus (except in the greater Minsk region) and the Ukraine regions have a lower share. Chechnya and the Moldova are the areas with lowest working populations and active populations.

We have seen how tricky it is to address the employment issue, due to a high rate of informal activity (see Sect. 1.3.2). Yet we know that GDP in Russia is centred on the Moscow and St. Petersburg metropolitan regions. The regions bordering the Urals eastern edge also have slightly higher GDPs than the regions bordering the EU. When looking at GDP per capita, the Moscow and St. Petersburg region are still dominating, but along with Murmansk, Belorod oblast and Tatarstan (one of Russia's most economically developed regions). Ukraine as a country was hard hit by the economic crisis and thus performs worst in GDP per capita, along with Moldova.

\subsubsection{Environmental}

The Eastern neighbourhood's countries share a number of common environmental challenges. Most of them are related to water quality, waste management, hazardous nuclear namely military activities, industrial pollution, obsolete pesticides, land, forest and biodiversity management, non-rational and depleting use of natural 
Table 4.1 Summary of major environmental challenges in the countries of the Eastern neighbourhood

\begin{tabular}{|c|c|}
\hline \multirow[t]{5}{*}{ Belarus } & Land degradation (wetland areas of Polesie) \\
\hline & Chernobyl disaster consequences \\
\hline & Hazardous industrial sites and polluting facilities \\
\hline & Stockpiles and disposal sites of toxic waste, incl. obsolete pesticides \\
\hline & Defence facilities and activities \\
\hline \multirow[t]{4}{*}{ European Russia } & Nuclear-waste and accidents \\
\hline & Erosion and degradation of land and water \\
\hline & Climate change \\
\hline & Deforestation \\
\hline \multirow{5}{*}{$\begin{array}{l}\text { The Republic of } \\
\text { Moldova }\end{array}$} & Land and water body pollution with mineral fertilizers and pesticides \\
\hline & Loss in biodiversity \\
\hline & Excessive use of natural resources \\
\hline & Excessive pollution \\
\hline & Soil erosion \\
\hline \multirow[t]{6}{*}{ Transnistria } & Degradation of water resources \\
\hline & Air pollution \\
\hline & Accumulation of solid household and industrial wastes \\
\hline & Reduction of the forest area and illegal cutting of forests \\
\hline & Degradation of land resources \\
\hline & Soil pollution with agrochemicals and pesticides \\
\hline \multirow[t]{5}{*}{ Ukraine } & $\begin{array}{l}\text { Hazardous and military activities (industrial and mining facilities, } \\
\text { radioactive contamination, hazardous waste) }\end{array}$ \\
\hline & Nuclear power and waste (Chernobyl) \\
\hline & Obsolete pesticides and industrial pollution \\
\hline & Water management and water scarcity \\
\hline & Land, forest and biodiversity management \\
\hline
\end{tabular}

resources, low energy efficiency, as well as pollution of the Sea of Azov, the Black Sea and the Caspian Sea (ENPI 2007) (Table 4.1).

The region's major environmental problem is related to the consequences of the Chernobyl nuclear accident in 1986, which continues to pose long-term environmental and health damages to Ukraine, the neighbouring Belarus and Moldova and Bryansk oblast in Russia.

Belarus and Ukraine were among the most industrialized countries in the former Soviet Union. Although, with the collapse of the Soviet Union, industrial production levels decreased significantly, the environmental problems linked to industrial processes remain. The deposits of industrial waste, obsolete pesticides and unsustainable mining practices from the past pose serious environmental risks today (i.e. the regions of Donbas in Ukraine and Soligorsk in Belarus) (ENVSEC 2010). In Belarus, one third of all pesticides are stored under unsuitable conditions (e.g. at farms or industrial facilities). Ukraine is home to about 16,800 tons of highly toxic 
and hazardous rocket fuel component 'melange' since 1961; the storage facilities are no longer safe but the country does not possess the capacity, both financial and technical, to recycle or dispose of the compound in an ecologically sound manner. Overall, low technological capacity results in higher emission levels, higher waste volumes from production processes, while insufficient treatment of industrial wastewater affects the stability of ecosystems.

Military heritage also left its mark on the region-toxic and radioactive material can be found in all countries of the neighbourhood. The decommissioning of nuclear submarines and disposal of nuclear waste is an on-going process in Murmansk and Arkhangelsk oblasts, where many of the submarines are still docked. Moreover, even today pollution at defence sites and facilities, as well as disposal of obsolete armaments are important issues for Belarus and the Caucasus region.

When it comes to radioactive and toxic waste, the countries often do not have suitable infrastructure and available financial resources to handle it. In the Republic of Moldova, for instance, there were about 8000 tons of toxic waste products in 2004 and no available disposal sites to store them.

Poor status of the water environment is another environmental challenge. The leading causes are weakly developed sewerage systems, industrial discharges and non-existant or out-dated wastewater treatment plants, but also agricultural pollution and soil erosion. In the Republic of Moldova, most sources of underground water do not meet water quality standards due to a high content of chemically harmful substances, such as fluorine, sulphates and chlorides (ENVSEC 2006). The pollutants have accumulated in seas with limited water exchange, such as the Caspian Sea, the Black Sea and the Sea of Azov.

- Water quality problems are severe in the Volga Basin in Russia. Volga is Europe's longest and among its most polluted rivers, as a result of the cumulative effects of overuse, untreated sewage and heavy industry. Volga's water is far beyond the quality norms for drinking water and is unsuitable for fish farming or irrigation. The Caspian Sea which receives about $85 \%$ of its freshwater from the Volga River is dramatically affected (Henry and Douhovnikoff 2008). The Caspian Sea is an example of excessive chemical pollution through running rivers (the Volga, Kura and Ural Rivers) and offshore and onshore oil and gas industry. Underwater oil pipelines which surround Absheron peninsula and some area of Mangyshlag are also among the sources of pollution of the Sea. During the Russia-Chechnya war, military waste was dumped into the sea. Today the Caspian Sea is also polluted by radioactive waste. The Sea is experiencing a decline in commercial fish stocks, such as Caspian sturgeon.

- The nutrients from agricultural, domestic and industrial sources and insufficiently treated sewage waters cause eutrophication and degradation of the ecosystems in these seas. Water quality of the Black Sea is affected by the polluted waters of the Dnipro and the Danube rivers which pass through Central 
Europe and the territories of Russia and Belarus before emptying into the Black Sea. In recent years, chemical pollution by oil and toxic substances has become a serious trans-boundary problem affecting the Black Sea.

- Exhaustive nature management aimed at fostering economic growth and active utilisation of aquatic ecosystem services of the Sea of Azov has left irreversible damages to the ecosystem (Lagutov 2011).

In all countries of the Eastern neighbourhood and in the Caucasus in particular, land degradation and desertification is a serious environmental challenge. Fertile soils are being exposed to degradation as a result of human activity, reduced deforestation, unsustainable agricultural practices and mismanagement. The lower Volga River was degraded beyond repair during the Soviet period. Wind erosion has affected the more arid parts of the North Caucasus and lower Volga River basin. In the Republic of Moldova the area of eroded land grows by approximately $0.9 \%$ each year which results in losses of 26 million tons of fertile soil.

The Eastern neighbourhood comprises about $30 \%$ of the world forest reserves which act as major sinks of greenhouse gases and play an important role from climate change mitigation perspective. Yet, illegal logging and corruption represent a major threat for forestry in the region. Most likely pressure to increase extraction will grow as the domestic and international demand for lumber grows.

\subsection{Baltic Sea Region: Case Study on the EU/Russian on-the-Ground Partnership}

\subsubsection{What Delineation?}

There is no precise definition of the boundaries of the BSR. From the geographical point of view, the BSR comprises the countries which have coastlines on the Baltic Sea (Sweden, Finland, Denmark, Estonia, Latvia, Lithuania, Poland, Germany and Russia). Normally, only the northernmost coastal regions of Germany are included (Hansestadt Hamburg, Mecklenburg-Vorpommern, and Schleswig-Holstein), northern Poland (Pomorskie, Warminsko-Mazurskie, and Zachodnio-Pomorskie) and some parts of the north-western federal district of Russia (Kaliningrad oblast, Leningrad oblast and Republic of Karelia). Moreover, the BSR comprises the areas which are in a drainage basin of the Baltic Sea. So, besides nine coastal states, there are five countries in the basin-Belarus, with almost half of its area in the basin, and smaller parts of Ukraine, Czech Republic and Slovakia draining through Poland, and very small parts of Norway. The whole drainage area covers 1.7 million square kilometer, and is home for 85 million people.

Other factors matter when defining the region. Norway is included due to its strong economic ties with the countries surrounding the Baltic Sea and willingness to participate in regional cooperation. The definition of the Region varies across different institutions and intergovernmental organisations. For instance, if the 
purpose of cooperation is environmental protection of the common water, then it makes sense to include the territories of Belarus which are in the drainage basin. The BSR is a highly heterogeneous area in economic, environmental, social and cultural terms, but at the same time the countries in the region share many common resources, have strong ties, common development trends and challenges (i.e. Baltic Sea environmental degradation) (EC 2013).

The Baltic Sea has brought people together for centuries by providing routes for trade and cultural exchange. In the Middle Ages until the 15th century, nearly a hundred cities in the BSR belonged to the Hanseatic League - a trading system which covered most of northern Europe. Economic ties with North-West Russia have traditionally been strong. Before the revolution in 1917, the St. Petersburg metropolitan area was a major export market for a number of eastern Finland's industries. Moreover, some areas of modern Russian Federation were previously foreign territories. Part of the Republic of Karelia belonged to Finland, while Kaliningrad was part of Prussia and, later, the German Reich before the World War II.

Integrative processes and cooperation in the BSR were hampered by historical events, including the Cold War. With the end of the Cold War, cooperation in the BSR resumed. Cooperation between the countries increased with further enlargement of the European Union, first Finland and Sweden in 1995 then the Baltic States and Poland in 2004. Today the BSR continues to benefit from exceptionally strong economic, social and trading ties in the region (State of the region report 2012). Development of the BSR identity would contribute to regional community viability and resilience, as well as improve overall understanding and conflict resolution.

\subsubsection{Russia Versus Rest of the BSR}

The Nordic countries have a long tradition of strong national and local governments. The local authorities carry out most of the planning activities sharing the responsibility with the national level, which is also referred to as the "Nordic approach". Cooperation between the administrative levels is well-functioning, partly due to a good coherence and a high level of trust between all governance levels. Public participation is a strong element of the Nordic culture, all the more as these countries have a strong civil society. The situation is quite similar in Germany, where power is divided between the federal governments and Lander.

On the other hand, the post-communist countries (three Baltic States and Poland) are lagging behind the Nordic neighbours in the field of governance. As young democracies, the priority in the 1990s was given to more pressing political and economic reforms, such as establishing an effective representative democracy rather than fostering public participation. During the last decades these countries made 
significant progress towards better governance, largely influenced by the EU accession process. Requirements for the distribution of EU structural funds have supported the regional level of governance. Despite the principle of subsidiary applied in the Baltic States, the challenges for the local governance remain. The municipalities here have little decision-making authority, few administrative functions and are lacking financial independence (Böhme 2013).

In Russia, local authorities historically have even less power. In the beginning of the 2000s, a policy of re-centralisation was taken, which diminished the newly found autonomy of regional actors. The majority of regions were subordinate to the central government, politically, economically and administratively, which limited opportunities for the regions to engage in international activities (Ross and Campbell 2008). In 2003, the Law on Local Governance implied decentralisation. However, the newly formed local self-governments remain weak and have limited financial independence, and have to focus on implementing activities delegated from the top. Corruption and the lack of transparency are additional challenges for the development of good governance.

When it comes to demographic dynamics, the North-South territorial divide is primarily influenced by diversified climatic conditions. The BSR consists of a densely populated southern part and largely uninhabited and sparsely populated northern part. Connecting the remote rural settlements in the North to the urban networks and providing sufficient transport infrastructure remains a major challenge for the development there. The population decline in the northernmost parts of the region is expected to continue, except in cities (Nordregio 2012).

But, as a whole, population dynamics rather display an East-West divide. The population in the Baltic States and North-West Russia is declining both in urban and rural areas due to low fertility and high outmigration. The North-West Russia is experiencing the sharpest population decline in the region by $0,5 \%$ annually and has fertility rates below western European averages, except for Kaliningrad oblast where the demographic situation is fairly good (State of the Region Report 2012; Sebentsov and Zotova 2013). High emigration rates of the working-age population from the Baltic States, Poland and the North-West Russia places an even higher burden on the remaining workforce in these countries. On the contrary, the population in the Nordic countries continues to grow due to high birth rates and immigration (e.g. from the Baltic States).

When it comes to economic dynamics, the East-West disparities are still visible two decades since the fall of the iron curtain (Map 4.4). GDP per capita in the western part accounts for more than $120 \%$ of the EU average, whereas it is less than $50 \%$ in the eastern part. Despite the financial crisis of 2008, the Baltic States are doing better. Before 2000 the prosperity levels in Norway were more than five times higher than in Latvia; today the ratio dropped to three-even if Latvia still remains one of the poorest countries in the EU.

There are also considerable differences within the north-western Federal District in Russia itself. The District consists of 11 federal "subjects" including 2 republics, 


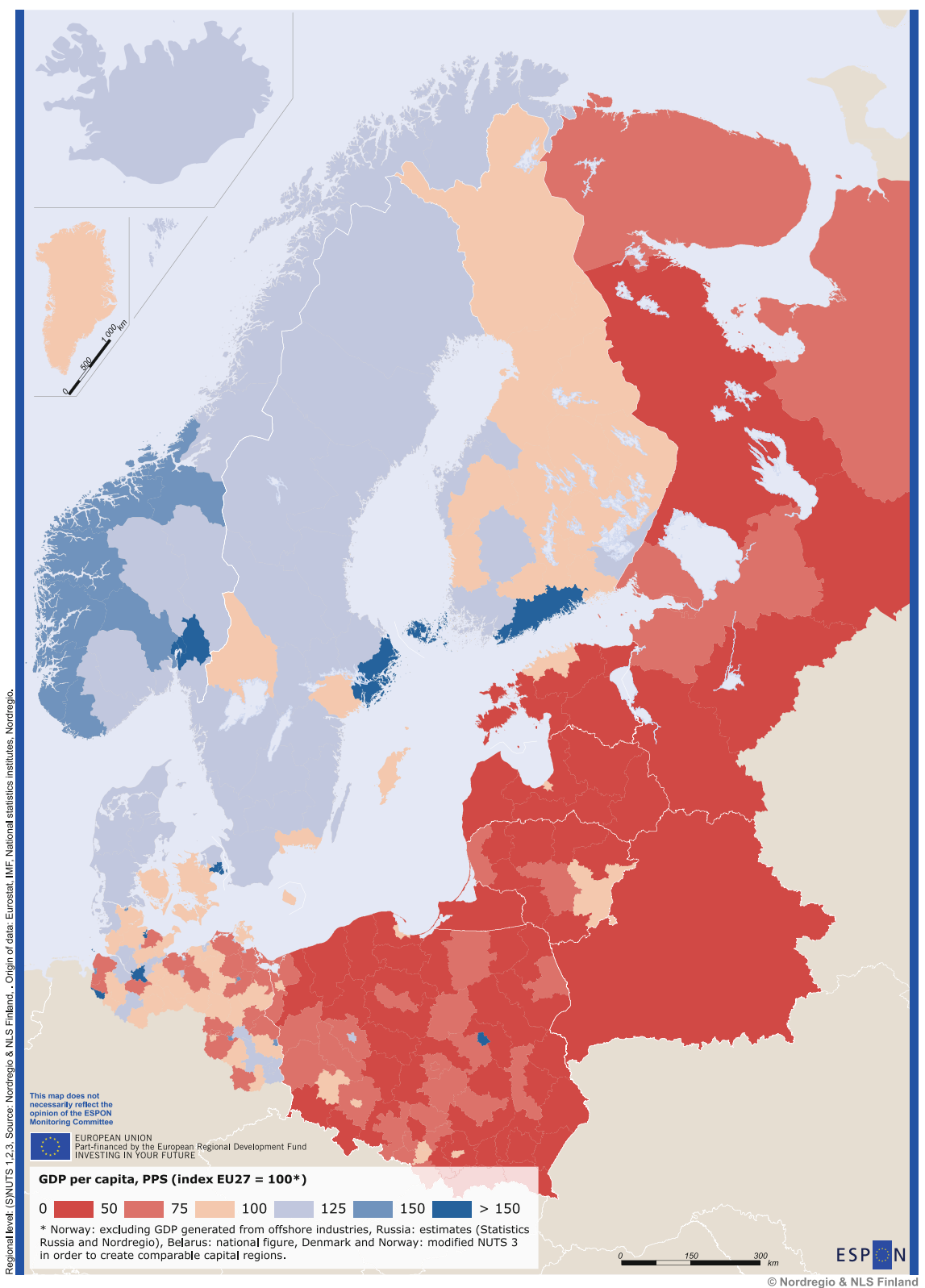

Map 4.4 GDP (PPS) per capita. An East-West economic divide, 2009. Source Nordregio 
7 oblasts, 1 federal city and 1 autonomous oblast. It borders with Finland, Poland, Estonia, Latvia, Lithuania and Belarus, and has access to the Baltic, White, Barents and Kara Sea. The area covers 1.6 million square kilometer, which is almost as much as the catchment area of the Baltic Sea. Leningrad oblast and St. Petersburg are the fastest growing of all federal subjects in Russia, whereas the Komi Republic and Murmansk oblast are ranked at the bottom. The economy of the Kaliningrad oblast can be characterised as fragile and unstable. The economic crisis in $2008 \mathrm{had}$ a worse impact on the exclave than other federal subjects of the north-western Federal District.

North-West Russia's economy is regarded as one of the most dynamic parts of Russia. Among the strongest industries in the Archangelsk and Karelia regions are forest, timber and pulp and paper; the fuel industry in Komi, ferrous metals in Vologda and Murmansk, and chemicals in Novgorod. Basically, EU/Russia trade shows a core-periphery pattern: the main imports from the EU to Russia are manufactured goods, services and food; Russia primarily exports raw materials to the EU.

Trade flows within the BSR are currently exceeding the trade flows outside the region. The Baltic States and Belarus have the highest shares of trade flows within the region, followed by the Nordic countries and Poland (Map 4.5). But despite (or because of) the communist past, the Baltic States and Poland have rapidly reduced economic ties with Russia. Estonia is increasingly oriented towards the Scandinavian trade blocks. Latvia and Lithuania are strategically turning to the western European countries. The unique location of the Baltic States on the crossroads between eastern and western markets is not fully used today.

Russian participation in the BSR economic integration is mainly limited to energy and transit projects, with Gazprom being the main investor. There are few Russian companies established in the EU part of the BSR. Although the volume of investment by the Swedish, Finnish and other transnational corporations in Russia is growing, the actual integration of Russian business into the BSR is still rather weak (Kuznetsov 2012).

Due to the growth of EU-Russia trade, complemented by inefficient procedures and inadequate infrastructure on the Russian side, long queues of lorries at crossing points from Finland, Estonia and Latvia have become commonplace. Simplifying the customs legislation and improving infrastructure in Russia will help avoid similar problems in the future (EUSBSR Action Plan 2013). The perspectives of the development of Kaliningrad seaport are not that bright, primarily due to high competition with the neighbouring ports of Klaipeda (Lithuania) and Gdansk (Poland), and to barriers related to customs and border crossing procedures which hinder the formation of a strong transport cluster in the exclave (Map 4.6). 


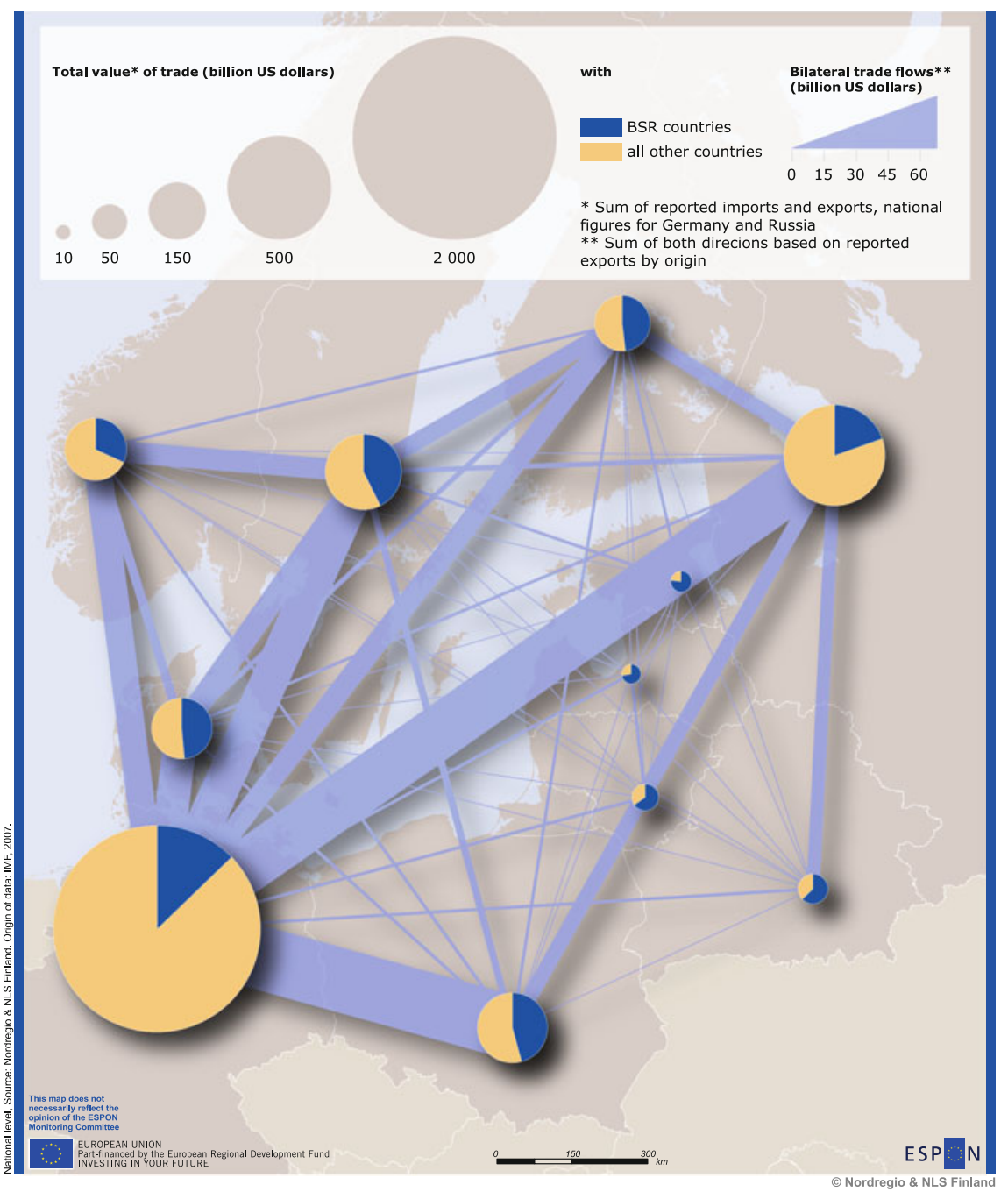

Map 4.5 Trade between the Baltic Sea Region countries, 2006. Source Schmitt and Dubois (2008), Nordregio

\subsubsection{Kaliningrad: Stumbling Block or Touchstone of the Cooperation with Russia?}

The Kaliningrad oblast is a special case due to its exclave status and geographical isolation from mainland Russia. The oblast is surrounded by EU countries, which influences the mindset of the residents. They often mention that they have a strong connection to the BSR and have developed a sense of a separate identity which is 


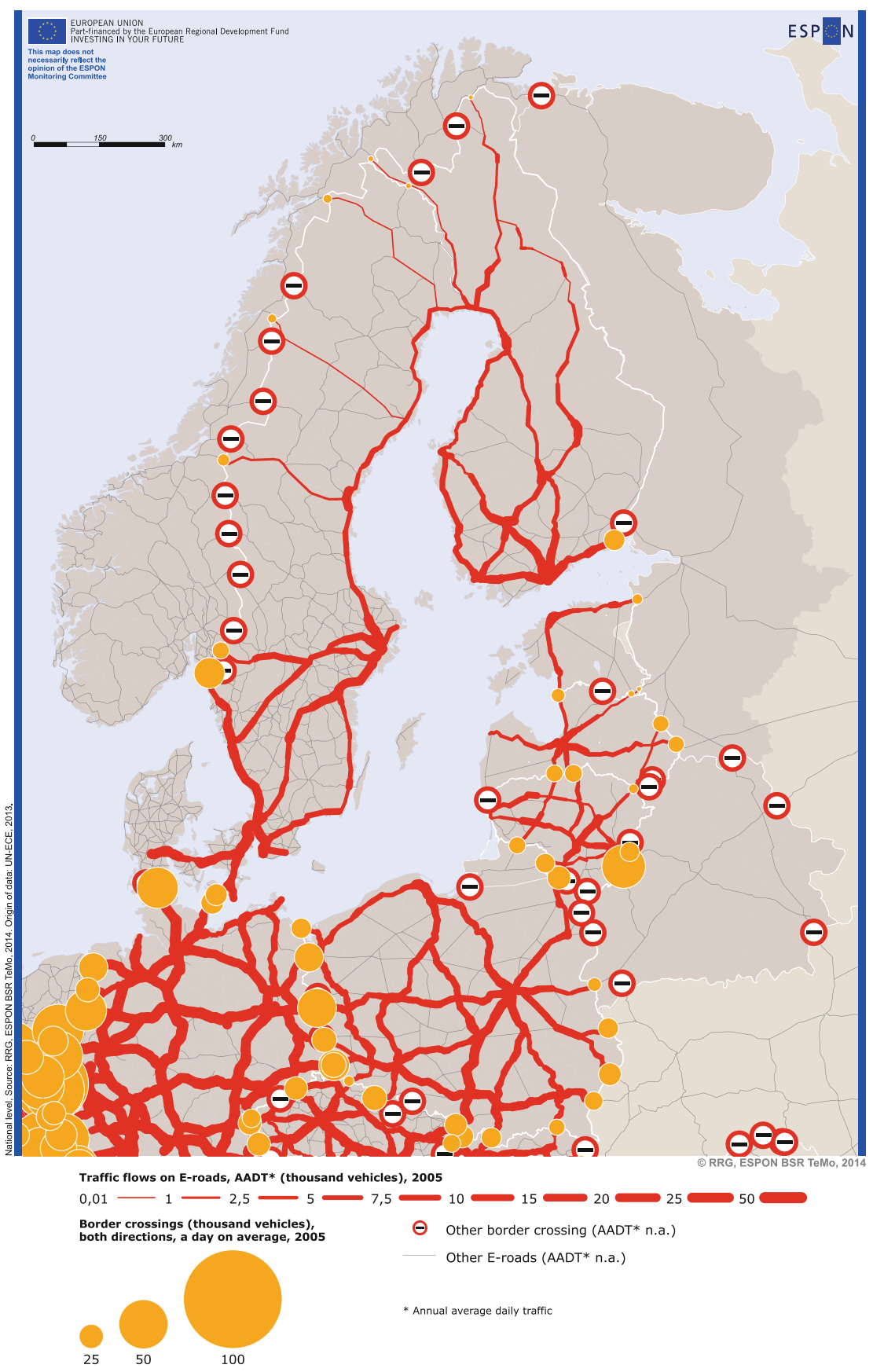

Map 4.6 Border crossings and E-roads in the BSR. Source ESPON Temo, 2014, Nordregio 
very close to Europeans (OSW 2012). There is a strong interest from the residents of the exclave in strengthening people-to-people contacts with the neighbouring European countries, cooperating in the field of culture, education, environment and social development issues.

Historically, Königsberg (now Kaliningrad) and its surroundings had been part of Prussia since the early 13th century. After World War II it was annexed by the USSR; millions of German residents were expelled, and the "Kaliningrad Oblast" one of the smallest subjects of the Russian Federation-was predominantly used as a military base because it is one of the rare Russian seaports on the Baltic free of ice year-round. Until 1991, Kaliningrad was a "closed" area, impossible for foreigners to enter because of its strategic importance for Soviet defence. In 1991, Kaliningrad became an exclave of the no longer socialist Russian Federation, cut off from its motherland by Lithuanian land, or Polish territory.

The city is among the greatest sources of pollution in the entire Baltic Sea basin. Due to weak development of sewage treatment plants in the urban centres and villages of Kaliningrad oblast, communal wastewater mostly goes untreated into the Neman and Pergola rivers. The lack of adequate waste management systems in Kaliningrad oblast represents a threat to the quality of groundwater.

Energy security is an important issue for Kaliningrad: in the event of a gas conflict between Russia and its neighbours, the oblast may experience the shortages of raw materials. This was the case in 2004 as a consequence of Moscow cutting off its supplies to Belarus. In 2011, Kaliningrad oblast produced enough power to meet its demand for electricity due to recently completed construction of (gas) heat and power plant. Since December 2011 the region's energy grid has been connected with the rest of Russia through the energy lines running through Lithuania. But the prices of gas and petroleum products in Kaliningrad oblast are in general higher than average Russian prices. Since 2009, Moscow has been interested in the construction of a nuclear power plant in Kaliningrad oblast. As long as its planned output is higher than the area's demand for energy, some of the energy would be exported, mainly to the EU member states. Construction of the Baltic nuclear power plant would, on the one hand, contribute to establishing a closer relation between EU and Kaliningrad oblast. On the other hand, along with environmental concerns, the construction of the nuclear power plant would increase EU dependency on the energy supply from Russia, and thus reduce the energy security of Poland and the Baltic States.

Both federal and regional authorities in Kaliningrad have long been interested in fostering the production and export orientation of the economy of Kaliningrad. For this purpose, and in order to attract foreign investments, a free customs zone regime in the framework of a Special economic zone (SEZ) was established here. The SEZ grants exception from the customs duties and custom fees to all goods produced in the SEZ if companies-large companies and not small or middle-sized ones-add $30 \%$ of added value locally and export to foreign countries or to mainland Russia. In general, there are also no import taxes in Kaliningrad with the exception of some categories of goods. 
The economy of Kaliningrad oblast is oriented towards openness and enhancement of foreign economic activities. After the collapse of the Soviet Union, the hopes were great for Kaliningrad to become the "Singapore" of Russia. The exclave has a vast trade deficit due to its underdeveloped economy and the fact that it is used mainly as a gateway to mainland Russia for foreign goods. With introduction of the SEZ regime, Kaliningrad was expected to develop exports to neighbouring EU countries. However, instead of expanding exports, imports grew on a mass scale. Imports account for over $90 \%$ of Kaliningrad's foreign trade: components for the assembly of cars and TV sets, household chemical products, food products, footwear, clothes and furniture. The key suppliers of goods to Kaliningrad are Germany, China, South Korea and Slovakia (Rogoża et al. 2012). In 2010 about 7 \% of all EU exports to Russia went through Kaliningrad oblast. Consumer goods and the items that are processed and/or assembled in the region and then sold in the other regions of Russia constitute the largest share of the imported items.

In spite of the considerable benefits of the SEZ regime, the investment climate and business environment in general are far from being good in Kaliningrad. Even though business activities, including foreign investments in the region, have increased over the last decade, the full potential of the region as a gateway to Russian, Baltic and wider European markets has not been used. Instability of federal tax and tariff legislation, as well as uncertainty about the SEZ regime in Kaliningrad are among the barriers to attracting foreign investments. Other barriers include the lack of adequate competences at the regional level and, typical for Russia as a whole, excessive bureaucracy, corruption and a poor legal culture. Moreover, there are no cheap flights to and from Kaliningrad to the outside world, as well as no trains. Isolation of the market from mainland Russia and higher business costs related to that (i.e. costs of energy, transit and imports), are amongst additional drawbacks; as a consequence, most of big businesses who want to implant in Russia go to other SEZs "inside" Russia. For the Oblast itself, the financing of the SEZ has been a high burden on the budget, combined with high tax losses. Lastly, the SEZ will close in 2016 because of Russia's joining of the WTO and the incompatibility of some of its provisions with WTO rules.

\subsubsection{Cross-Border Cooperation as a (Fragile) Means to Foster Ties with Russia}

Border areas often share common problems. At the same time, geographical proximity to the border can present opportunities. This has been the case for the forestry sector in eastern Finland and the neighbouring Republic of Karelia, which has benefited from a proximity to the border due to lower transport costs and direct economic contacts. The border municipalities and regions in North-West Russia (particularly the Leningrad region and Vyborg municipal district) have also benefited from the proximity to the border and the development of Russia's oil and gas 
transport infrastructure. The on-going investments to develop Leningrad region's harbours strengthens this geographical asset.

The cross-border cooperation between the EU and North-West Russia has been quite successful, especially the bilateral relations between Russia and Finland-in spite of the historical antagonism between the two countries. Until the economic crisis in 2008 bilateral trade and investments grew significantly, with Leningrad region being the main gateway. During the years 2006-2010, investment in the Leningrad region by the Finnish companies accounted for about $16 \%$ of total Finish investments in the Russian Federation. During the last decade several cross-border entrepreneurial networks emerged between south-eastern Finland and the Leningrad region (Zimin 2013).

At the same time, emerging economic ties and cultural cooperation in the EU-Russia borderlands are highly sensitive to the market fluctuations and unsteady institutional framework, including the border regime. Looking at the forestry sector as an example, opening up of the Russian border for trade in the early 1990s positively influenced the development of markets for raw materials in the forestry sector. During this period, Finnish imports of round wood from Russia grew substantially, which enabled Finland to expand the production industry by processing timber. In 2007 Russia introduced export duties for timber to encourage domestic processing of raw materials, which resulted in a sharp decline in trade of round wood to Finland.

In case of Kaliningrad oblast, the years 1999-2003 were the most successful for cross-border cooperation. It was carried out between the non-governmental organisations and the regional authorities. However, enlargement of the EU in 2004 brought closer attention of the Russian central government to the region.

As Richard et al. (2015) state, "although the economic and social conditions exist for the rapid integration of the Kaliningrad Oblast in the Baltic region, one must admit that cross-border cooperation has hardly developed (...), in a particular geopolitical context where Kaliningrad has become a double periphery of Russia and the EU'. According to them, and along with the tense geopolitical context between the EU and Russia, the rising but still poor development of exchanges with the surrounding territories of Poland and Lithuania is also caused by the persistence of social representations in local public opinion that hamper cross-border relations. The Kaliningrad region could be a model of interaction between Russia and the EU, they say. However, the present situation suggests that this area "may sink into a double distrust atmosphere, lead to the militarisation of border regions and the limitation of cross border cooperation".

\subsubsection{Commonalities for Regional Integration: Transport, Environment, Tourism}

Significant deficits in the quality and efficiency of transport infrastructure can be observed when travelling from West to East (Baltic States-Russia direction), such as fragmented motorway sections and a relative lack of electrified double-track 
railway lines, which hinder mobility of goods and persons despite recent improvement. In addition, institutional obstacles at the border crossings impede a better integration of North-West Russia and Belarus with their EU neighbours.

The Baltic Sea is among the busiest shipping routes in the world with steadily increasing traffic volumes. Maritime industries, such as fisheries, ship building, port-related services and supply chains, are important industries and have an important contribution to the regional integration and development. Moreover, marine and coastal areas are used for recreational activities and tourism. The Baltic Sea waters are also used for production and transport of fossil (e.g. Nordstream) and renewable energy.

Development of industries and trade, intensification of agriculture and other anthropogenic activities have contributed to the environmental degradation of the sea. The Baltic Sea is highly vulnerable to pollution due to a limited water exchange and low oxygen volumes. Eutrophication, contamination by hazardous substances and loss of biodiversity are the main challenges to the ecosystem today. Climate change also presents a serious concern, both through indirect (e.g. changed land use, water runoff) and direct effects (e.g. increase in water temperature). Addressing these challenges requires joined efforts taken by all countries in the catchment area. Green growth is an important topic for the prosperity of the entire Baltic Sea macro-region. European countries have, overall, more expertise when it comes to deploying sustainable solutions and promoting green growth. According to the association for economic interaction of the subjects of the North-West region of the Russian Federation (Association North-West) the environmental protection will be one of the perspective directions for cooperation between the Russian Federation and the EU in the BSR (BSR 2012).

The major problems in the North-West Russia are high levels of water and air pollution, the lack of environmental infrastructure, the lack of regulations which would force businesses to respect the natural environment, and a low environmental awareness level of the population. Among the most acute problems is a poor quality or lack of waste water treatment systems and poor waste management. Improving the environmental situation through promoting the implementation of projects of construction and modernisation of municipal sewage treatment plants, sewers, enterprises for the sorting and recycling of waste were among the priorities of the Russian presidency of the CBSS (2012-2013). With EU aid a sewage treatment plant was built in Gusev (Kaliningrad oblast), and a few others have been modernised. Kaliningrad's efforts to reduce the amount of waste entering the Baltic Sea were also supported by the federal programme for developing Kaliningrad oblast until 2015. The Swedish international development co-operation agency (SIDA) also contributed over US\$17 million in 2003-2007 for the construction and modernisation of water and sewage infrastructure and sewage treatment plants in Kaliningrad oblast. Further developments in this field are needed to contribute to pollution prevention in the Baltic Sea. The actions should also include consultations, experience exchange and trainings of representatives of stock-raising and poultry farms in the BSR. 
Tourism development and promotion of macro-regional tourist products (development of joint international tourist programmes together with neighbouring European countries are among the objectives in the Russian Strategy of social and economic development of the North-West Federal District set up in 2011. In addition, creating a network of recreational clusters based on sustainable tourism development was among the priorities of the Russian presidency of the CBSS. Tourism development also coincides with the objective of the EUSBSR, which is to foster Baltic Sea regional identity. Therefore promoting sustainability in tourism, together with cultural and historical heritage, could be among the focus areas for joint Russian-EU international tourist programmes in future.

\subsubsection{The Key Issue of People Mobility}

In the Baltic States, regional integration is of high importance for many individuals who have relatives, friends and cultural ties with Russia and Belarus and vice versa. Simplifying a visa regime could be an important step towards integration. Let us see what the starting point is.

Despite a varying degree of success in developing cross-border cooperation with the authorities and regional actors in North-West Russia, human mobility in its various forms is at stake. Since the early 1990s and the following expansion of the EU the number of Russians crossing the border has increased substantially. In Finland, Russian nationals account for about three quarters of the total number of border crossings today. The most common reason is day trips or shopping, which make a valuable contribution to the Finnish economy. Besides that, Russian-speaking residents are now the largest group speaking a foreign language in Finland, followed by Estonian-speakers. Moreover, Finland became an important tourist destination, several thousands of Russians come there yearly for seasonal or temporary jobs.

Residents of Kaliningrad tend to travel to EU countries considerably more often than the residents of other Russian regions. The data from 2011 shows that around 215,000 visas to the EU countries (out of 941,500 residents of the exclave) were issued. Since the region is dependent on external supplies (from Russia and abroad), goods and services in neighbouring countries become more attractive and competitive: not only shopping centres, but also resorts and clinics in Poland and Lithuania. Gradually, these countries are becoming a point of reference in terms of living standards, including the quality and prices of goods and services. The average cost of a food basket in Gdansk is approximately $20 \%$ lower than in Kaliningrad, while the cost of gasoline is much higher in Gdansk than in Kaliningrad.

Conversely, a Russian entry visa is required to travel to Russia for all EU nationals no matter what the purpose of a visit is. Business, private, humanitarian, work and student visas are issued for a period of up to 3 months. In the case of business and humanitarian visas it is possible to obtain a multiple entry visa, which is valid for 1 year. In most cases a visa invitation from a receiving party 
(e.g. company, relatives, friends, educational institutions) from Russia is needed. Tourist visas are valid for up to 30 days and can only be used for one entry.

The Russian Federation visa-free regime for up to 90 days was valid for citizens of Ukraine and Moldavia. Citizens of Belarus do not require a visa and can stay in Russia for an unlimited period. There are few possibilities for a visa-free entry to Russia. Stateless persons who were former citizens of USSR and now residing in Estonia and Latvia (holders of alien and non-citizen passports in Estonia and Latvia respectively) can enter Russia without a visa for a period of 90 days. Since 2009, cruise ship passengers travelling to the BSR ports of Kaliningrad, Vyborg and St. Petersburg can stay in Russia for up to $72 \mathrm{~h}$ without a visa on condition that the tours are booked through the travel agencies authorised in Russia.

When travelling to the Kaliningrad region, citizens of Schengen states, UK and Japan can obtain a $72 \mathrm{~h}$ tourist visa at the border check points of Bagrationovsk, Mamonovo and Khrabrovo Airport, if traveling through an approved travel agency. In all other cases a Russian visa cannot be obtained on arrival but only through the Russian Consulates and Embassies. A bilateral local border traffic agreement between Kaliningrad and neighbouring Polish regions was signed in 2011, which represents significant progress in visa-free talks. From 2012, the residents of the Russian exclave who use local border traffic are allowed to stay in Poland for a period of thirty days (but no longer than ninety days within every six months). In 2013, the Russian ministry of Culture proposed a draft bill aiming to introduce a 72-h visa-free transit for foreigners from 20 countries (including the BSR countries Finland, Sweden, Germany and Poland) on condition that they travel with a Russian airline carrier. Among the eligible airports included in the proposal are those located in the BSR-Pulkovo in St. Petersburg and Khrabrovo in Kaliningrad. Making Kaliningrad a pilot region for establishing visa-free movement into the entire EU has been discussed for years.

\subsubsection{Intergovernmental Institutions Include Russia but not Always Efficiently}

There are a number of intergovernmental organisations established in the BSR, which have been dealing with regional development issues for more than twenty years and of which Russia is an active member. So, a solid basis for development of cooperation has existed for decades. The existence of these structures can be seen as an important driver for neighbourhood integration.

Adopted in 2009, The European Union strategy for the Baltic Sea region (EUSBSR) is the first macro-regional strategy in Europe. It involves eight EU member states around the Baltic Sea and promotes cooperation with Russia and Belarus. The thematic pillars are: environmentally safe region, prosperous region, accessible and attractive region, and safe and secure region. Russian actors can be involved in the EUSBSR flagship projects as associated partners, but the Strategy was elaborated without full-fledged participation of Russia and the country is excluded from the decision making process. 
In the framework of the European Neighbourhood Policy, Cross-border cooperation (CBC) is a key priority of the ENPI. Russia is a beneficiary of four CBC programmes co-funded by both the EU and the Russian Federation (220 million $€$ for the period 2007-2013).

VASAB (Visions and Strategies around the Baltic Sea) is an intergovernmental network of eleven countries of the BSR including Russia and Belarus which was established in 1992. It promotes cooperation in the field of spatial planning and development.

The Council of the Baltic Sea States (CBSS) is an overall political forum for regional inter-governmental cooperation established in 1992. Members of the Council are the eleven states of the BSR, as well as the European Commission. The Council provides a unique regional platform for cooperation between EU member states and the Russian Federation. The long-term CBSS priorities are economic development, environment, education and culture, energy and civil security. Since 2013 the CBSS Project Support Facility (PSF) has provided co-financing to the development and implementation of Baltic Sea macro-regional cooperation projects. PSF allows the involvement of Russian actors on an equal footing.

Initiated in 1999, the Northern Dimension (ND) policy plays a vital role in overall cooperation in the BSR, especially when it comes to developing cross-border cooperation with Russia. ND envisages equal participation of EU member states, the Russian Federation, Norway and Iceland. The ND partnerships provide a good platform for projects of macro-regional significance in culture, environment (including nuclear safety), public health, transport and logistics. However, some difficulties occurred, namely failure to meet many of these projects' co-financing requirements by the Russian side (for instance for modernising the water-and-sewerage networks in Kaliningrad). Among the projects that are usually implemented successfully are so-called 'soft' projects in the field of youth exchange and training events.

In sum, Russia is involved in the BSR intergovernmental cooperation via the Northern Dimension and to some extent via the CBSS and VASAB. But without the active participation of Russia in the EUSBSR, coherent sustainable development of the BSR cannot be achieved.

\subsection{Black Sea: Case Study on the Local Ties with EU and Russia}

\subsubsection{City Twinning: Balanced Partnerships with the EU and Immediate Neighbours-Especially Russia}

It is relevant to address the international cooperation at a local level, and observe if the cities that border the Black Sea are keen to collaborate together. A database has been compiled for 102 cities located in the Black Sea Region and the country of the 
cities with which they concluded twining agreements. 207 partnerships-a third of the total-have been made with Black Sea countries (i.e. countries bordering the Sea), especially with Russia, Bulgaria and Turkey. Another third have been made with EU countries (except Bulgaria and Romania), especially with Italy, Germany and Greece.

Before the collapse of the Soviet Union, the majority of partnerships were established with EU countries. Since the 1990s, more were undertaken with other Black Sea countries, the USA and Asian countries. Recently, in the 2000s, new areas for twinning partnerships emerged, such as with the European Mediterranean neighbourhood and Western Balkans.

In the post-Soviet states, partnerships are often with other parts of the former Soviet Union: Russia, Ukraine and Belarus. In Romania and Bulgaria, the partner cities are mainly located in the EU; from a local point of view also, this membership really translates into further integration with the EU (Map 4.7).

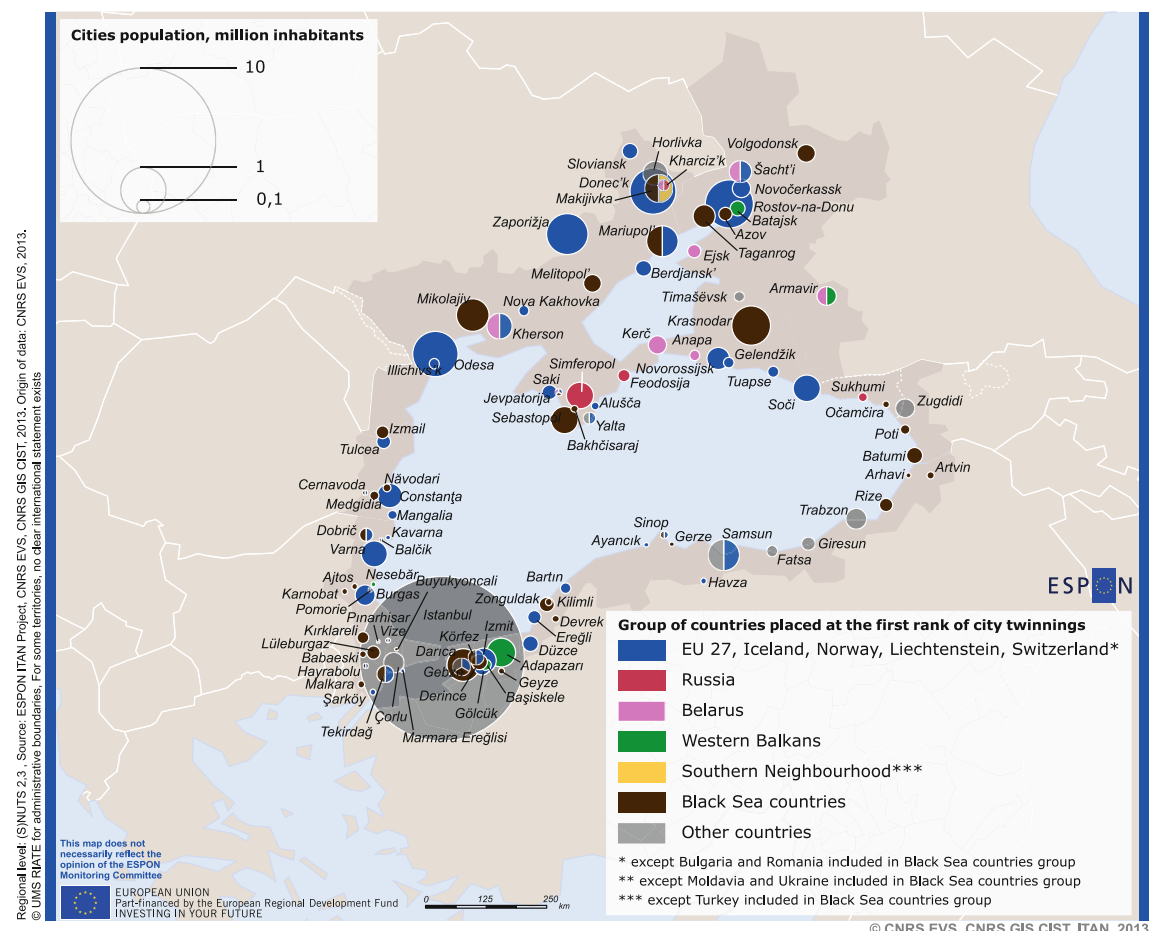

Map 4.7 Twinning of the Black Sea cities: regional breakdown 


\subsubsection{Diplomacy Networks of the Black Sea Countries: Rather with the EU or with Russia?}

Influence can also be measured through embassy networks. The ITAN project compiled the addresses of resident and non-resident embassies in the region. The database indicates with which countries the Black Sea countries have a resident embassy and in which capital cities they do not have these embassies. In the latter case, diplomatic relations are supported by a corresponding embassy situated in another country, which is, as a consequence, competent for more than one state. For example, Iceland only has 11 embassies in the area but has diplomatic relations with 43 countries. This means that Iceland's diplomatic relations with 32 countries are made through the competence of a "non-resident embassy". For its relations with Italy, Iceland uses the Icelandic embassy in Paris; the Parisian embassy is said to be the corresponding embassy of the non-resident embassy in Italy.

In the Black Sea Region, Moscow and Ankara are among the cities with the highest number of embassies; Turkey and Russia inherit long histories as states and empires. According to our database, $100 \%$ of the countries that have diplomatic relations in Russia do have an embassy located in Moscow. On the contrary, Tbilisi and Chisinau are narrow diplomatic places in matter of number of embassies. In general, only the most powerful countries in the world can afford to build and maintain embassies even in small states. This means that many countries in the world that have diplomatic relations with Georgia do not have embassies in this country; the question is: where, then, is their non-resident embassy in charge of their diplomatic links with Georgia located? Answering this question displays a picture of the diplomatic dependence of the Black Sea countries. Indeed, most of the Black Sea countries, which are middle-sized or small-sized diplomatic places, and have a lot of non-resident embassies: Turkey and Russia host a great number of non-resident embassies for Georgia; Romania and Ukraine host a great number of non-resident embassies for Moldova-whereas Germany and Russia host a great number of non-resident embassies for Romania. Black Sea capital cities can also host embassies competent for countries outside the region: Bucharest and Sofia host a lot of embassies competent also for Serbia, the Former Yugoslav Republic of Macedonia and Albania.

Map 4.8 gives the resulting picture for the diplomatic links as a whole with the Black Sea countries. A large part of the diplomatic dependence of the Black Sea countries, especially Ukraine, Bulgaria and Georgia, is on Moscow; Bucharest and Ankara are secondary centres. The other main hosting city of Black Sea non-resident embassies are EU capital cities, especially Berlin, Roma and Vienna.

The Black Sea region is a fragmented area. Initiatives to create some integration at a supranational level remain shy. The interests of the different Black Sea countries are too divergent for rapid development of such initiatives. Economic and demographic trends are also quite divergent; they divide the area between Turkey, 


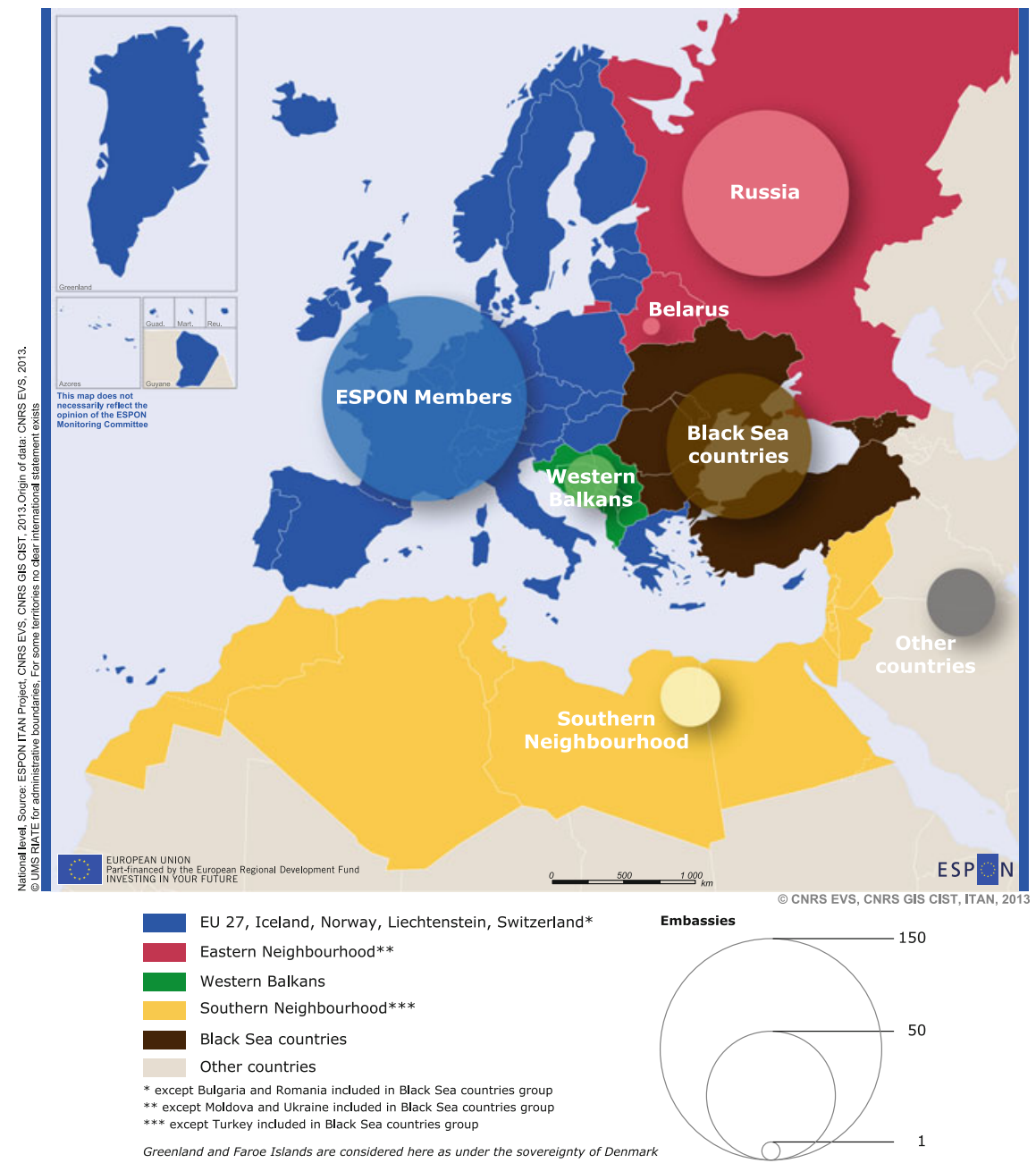

Map 4.8 Diplomatic links in the Black Sea region. Location of the resident embassies not directly housed in the Black Sea countries

which is experiencing rapid growth, the other Black Sea countries with weak economic growth (except Russia), low fertility rates and large diplomatic and economic dependence on EU members or Russia. The European Union is the main trade partner of the Black Sea countries and the main partner for city twinning, diplomatic links or port traffic; but this polarising role is rather declining, whereas Turkey and Russia's influence are on the rise. 


\subsection{Ukraine: Case Study on the Territorial Divide and Cohesion of a Contested Country}

The recent turmoil in Ukraine shows how important it is to consider the evolution of territorial patterns in political decision-making, in particular regarding the EU neighbourhood. This section describes the main features of recent territorial development in Ukraine at the regional scale (oblast). ${ }^{1}$ Though it does not allow following detailed changes, such analysis underlines the major trends of the country dynamics - for example, a sharp increase of the economic role of the capital city typical for most post-socialist States. Ironically, the on-going crisis in Ukraine, which raises the issue of national cohesion, takes place after a period of strong reinforcement of the capital city. The growing gap in wealth between the capital and other regions is one of the factors undermining the nation-building of modern Ukraine.

\subsubsection{Ukraine in Its Macro-Regional Context: A Fragile Interface Between Europe and Russia}

Ukraine plays a key role in the delivery of Russian energy resources to Europe: $60 \%$ of the Russian gas consumed in Europe transits through Ukraine. In the last decade, Russia has developed alternative routes: the North Stream (under the Baltic Sea directly to Germany, see Map 4.9) and the Blue Stream to Turkey. The South Stream project under the Black Sea to Balkan Europe is under construction.

Both the EU and Russia tried to convince the former Ukrainian leadership of the advantages of economic integration with them. The EU suggested signing the ENP Association agreement while Russia insisted that Ukraine joins the Eurasian Custom Union under Moscow's leadership. Each side argued that the maintenance of close economic relations was incompatible with integration with the other partner and thus considered it as a zero-sum game which triggered the current crisis in November 2013, when Russia requested Ukraine join the Eurasian Custom Union before signing the Association agreement during the Oriental Partnership Summit.

The EU and Russia were the main partners of Ukraine as regards to foreign trade, and its most important sources of foreign direct investments. They are also the main destinations of Ukrainian emigration. The EU provides Ukraine with the largest part of foreign aid. The territorial distribution of flight connections reflected this situation. In relation to population, Russia, as trade partner (import + export), was much more important for Ukraine than the EU member states. The legacy of the common Soviet past clearly showed in the distribution of exports: Russia was a

\footnotetext{
${ }^{1}$ The analysis partly derives from debates that took place during the international conference of the CIST held in Paris on March 27- 28th 2014. See in particular the debates with Jacques Sapir on http://www.gis-cist.fr/cist2014-compte-rendu/.
} 


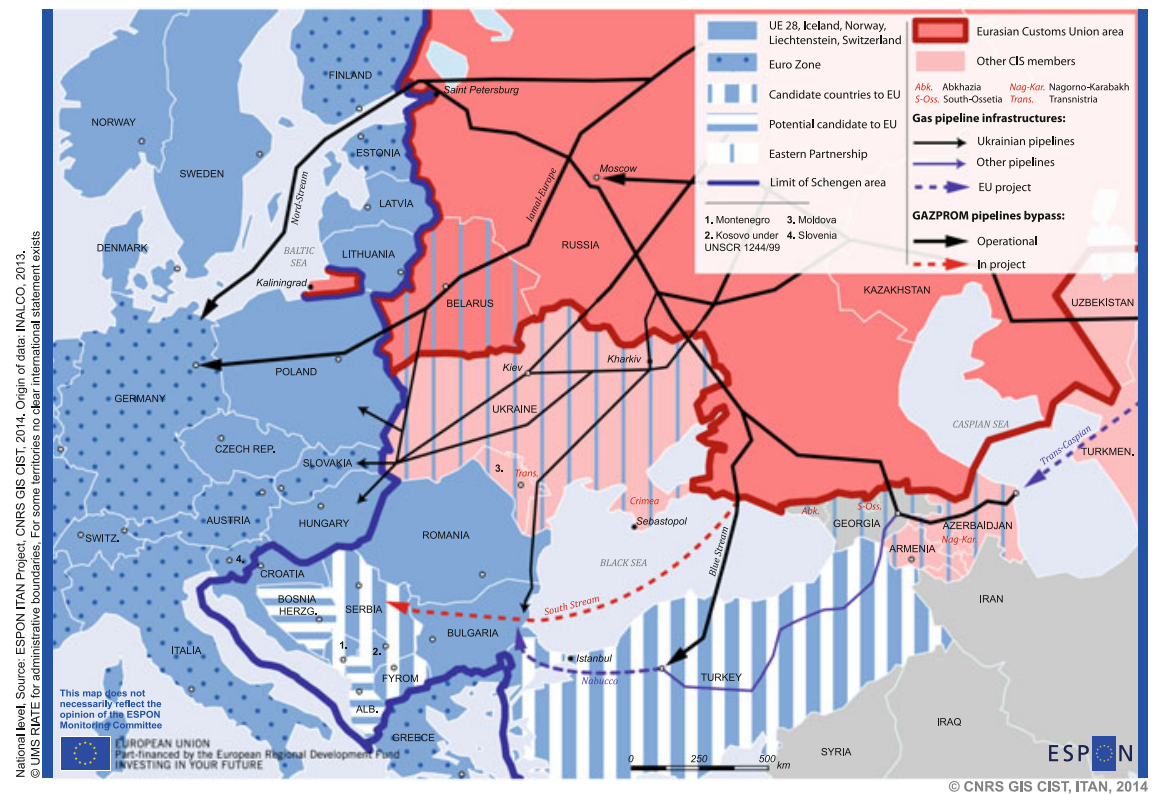

Map 4.9 The geo-economic context of Ukraine, 2013

much more important foreign consumer of Ukrainian goods than the EU. Figure 4.1 shows that the EU share in Ukrainian trade has been rising in the 1990s but is declining since the 2000s (Teurtrie 2012).

In the last decade, the Ukraine economy has shown successive indicators of weakness. The gap between Russian economic growth and that of Ukraine has been rising since 2003, because Ukrainian productive system has not been modernising quickly enough and needed massive investments. Since 2005 Ukrainian trade deficit has been deepening and since 2006 Ukrainian public debt has been rapidly increasing. As a result, Ukraine's path is decreasingly resembles that of an emerging economy; the country stands as one of the poorest area of the Europe Eastern neighbourhood, along with Georgia and its breakaway parts-Abkhazia and South Ossetia. The Western part of Ukraine shows a particularly low level of development. The contrast is obvious compared to Russia, and even to Belarus which has been doing somewhat better than Ukraine since the 2000s. Still, the situation in eastern Ukraine, the most industrialised and urbanised region, has been more favourable, partly because of its rapid depopulation (GRP per inhabitant rises when population declines). This development was in striking contrast with the progress of most regions of Turkey and of the neighbouring Russian Krasnodar krai. 

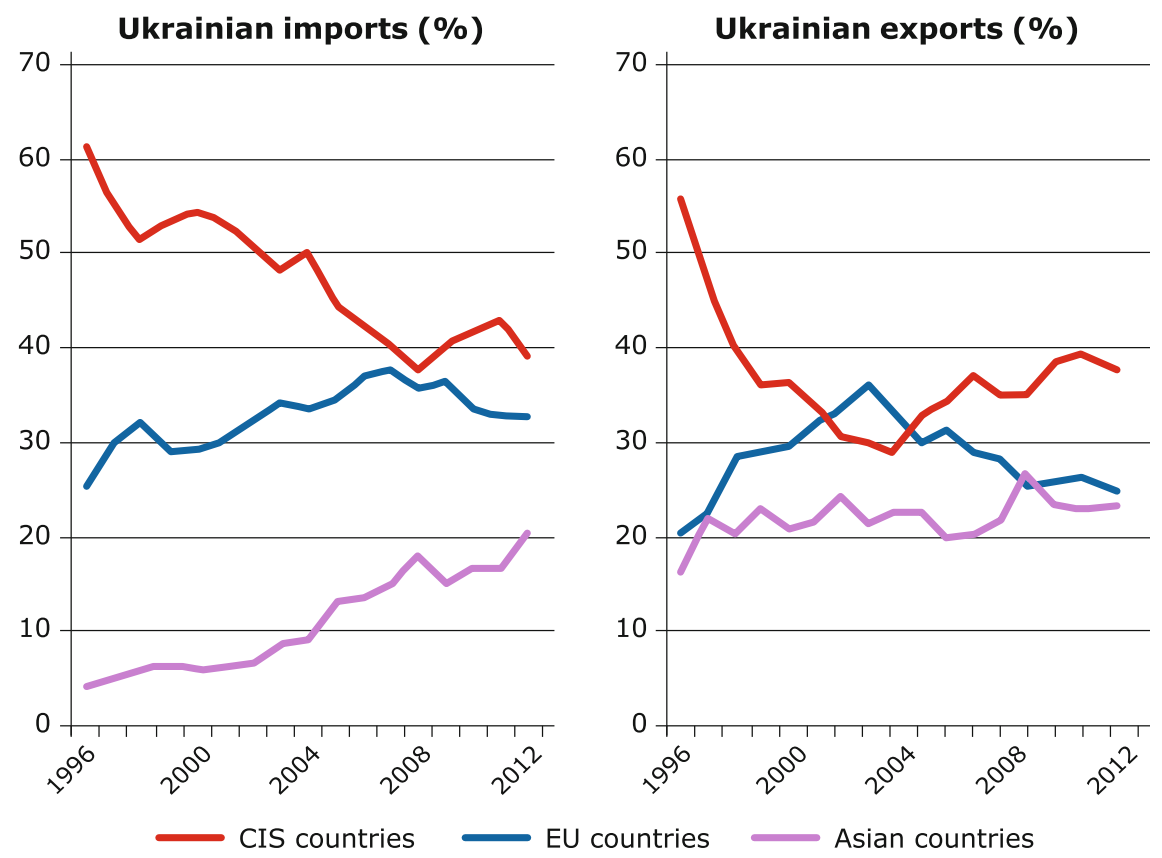

Fig. 4.1 The external trade of Ukraine: the declining role of Europe (in \% of Ukrainian trade, goods + services, values). Source Ukrstat

\subsubsection{Nation-Building, Declining Regional Disparities, Rising Concerns}

Another striking feature of Ukraine during the last decade is the rising regional issue. Ukraine has basically only existed in its present boundaries since World War Two. Before, western Ukraine had never been a part of a single State with other regions. Crimea was included in Ukraine territory even later (1954). Besides, unlike core Ukrainian areas, south-eastern and southern regions have been populated relatively recently by Ukrainian and Russian settlers-since the late 17th century and especially in the period of industrialisation in the late 19th century. Therefore regional cultural, economic and political disparities became one of the problems for the Ukrainian independent State.

Moreover, during the last decade territorial disparities have been deepening:

- the West still remains much less urbanised; its agriculture remains an important share in GRP. The region suffers from under-equipment and is lagging behind national income average,

- the East possessed a strong industrial basis and concentrates the largest cities; it was richer than the national average, 
- the centre of the country has an intermediate position, except for the city of Kiev and its oblast which are the most dynamic territories, with numerous civil servants and a set of business services.

Ukraine's population has been steadily declining; nowadays it has 46 million people (its mid-1960s level), compared to 53 million in 1993. Reasons for this decline are both natural decrease, and emigration almost equally distributed between EU countries and Russia. During the 2000s, no single region in the country experienced demographic growth, except the city of Kiev. Depopulation is particularly strong in the East (regions of Donetsk, Lugansk) and also in the oblasts of Chernihiv, Sumy, Poltava and Kirovograd. This process is closely related to the ageing of population. In the East and Crimea, the share of children under 16 dropped under $13 \%$. Most oblasts have a negative migratory balance. The few exceptions include primarily Kiev and its outskirts, and to a much lesser extent Odessa, Kharkov, and Crimea with its sea resorts and the city of Sebastopol which, as a Russian naval base, has always had a specific status.

Regional income disparities are very high: in 2010 income in the City of Kiev was more than double the national average. The East runs second. The lowest incomes are in the West. Since the collapse of the Soviet Union, in the eastern industrial regions wages have been severely declining compared to the national average. On the contrary, during the modern nation-state building era, the relative average amount increased in the West and especially in Kiev.

The East remained the main source of Ukrainian exports: exports per capita value was particularly high in the regions of Donetsk and Dnipropetrovsk, which provided more than a third of the country exported goods, mainly iron ore, rolled steel, basic chemicals and fertilizers. The city of Kiev also appears as an important exporter since it hosts the headquarters of many important companies whose production units are located in other regions (regionalised data on foreign trade are always questionable); but the imports of Kiev are even larger, thus its trade balance is highly negative. Therefore, Ukraine earned most of its foreign trade revenues thanks to industrial exports from its eastern part. CIS countries, especially Russia, were its main trade partners, particularly when considering that $8 \%$ of foreign trade, which mostly consists of "undocumented" natural gas coming from Russia was not regionally distributed by national statistics. Ukraine and Russia have for centuries belonged to the same single economic space, and economic links inherited from Soviet times were still strong, especially in the East.

\subsubsection{Conclusion: A Jaws Effect in the East}

Map 4.10 provides a synthetic typology:

- The city of Kiev benefitted from developments in the post-Soviet period thanks to relatively high incomes, the rapid growth of wages and consumption manifested in the highly negative balance of foreign trade. This explains a significant 


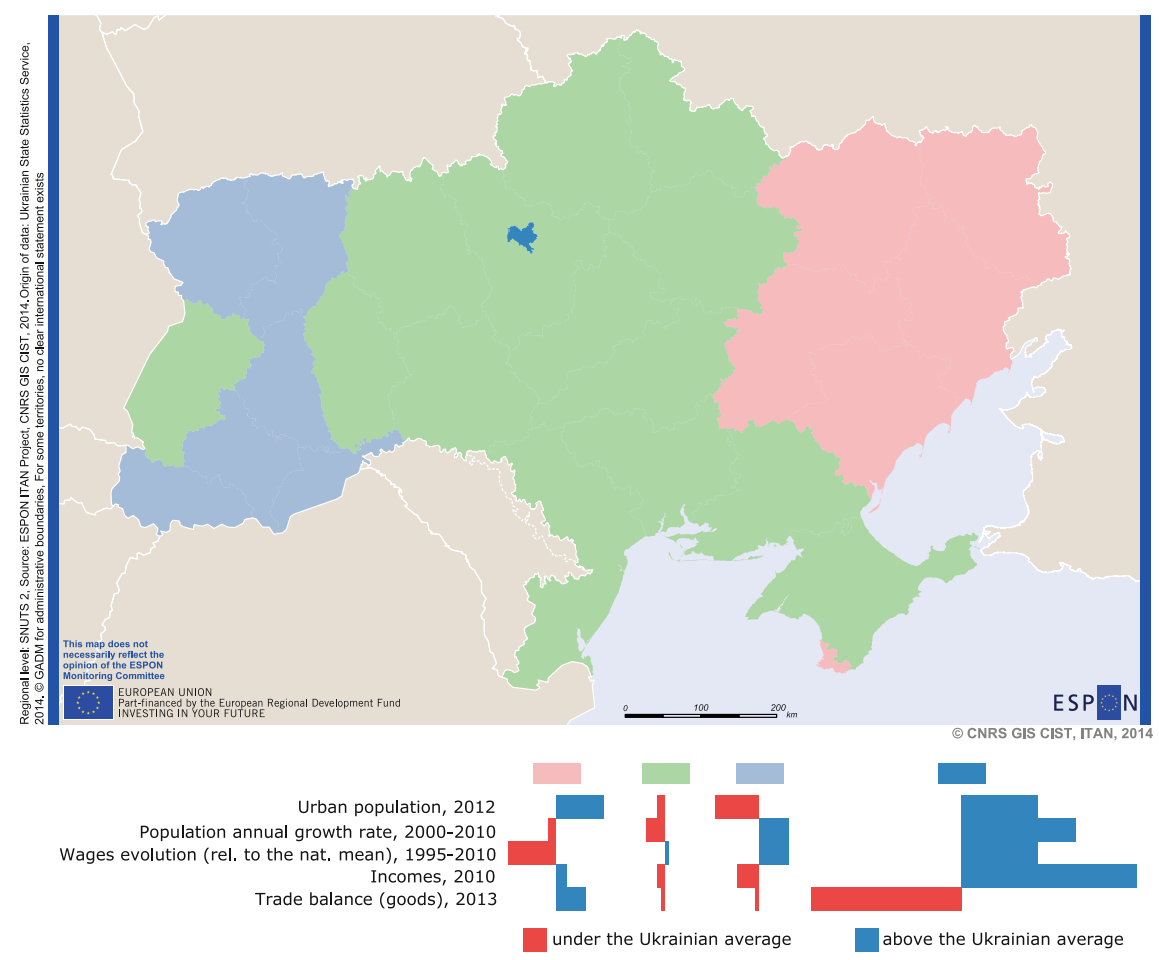

Map 4.10 Ukrainian regional typology, ca 2012

increase in the capital population-a striking contrast compared to the rest of the country - thanks to migration from all other regions, in other words a typical nation-building pattern.

- The position of the West slightly improved but only in relative terms. It remains less urbanised and poorer than the country as the whole, although its demographic situation is better and wages have been rising.

- The central part of the country is close to national average by all indicators.

- As for the East, since the end of Soviet times, it highly contributed to the modern national-building era: it remained the main source of export income for the country; it gathered the most important taxpayers since per capita incomes and salaries were significantly higher than national average (even if the informal economy is lower than in the rest of the country where revenues are therefore under-estimated); it sended its youth to the capital region, suffered from depopulation and had a negative net balance of migration. All of this happens in the context of an ageing population, sluggish economic growth and declining wages compared to the rest of the country. The East kept strong economic relations with Russia, particularly in the engineering and manufacturing sectors that depended on exports to Russia: eastern regions had a positive trade balance with Russia, and many large factories belonged to Russian companies. Such a 


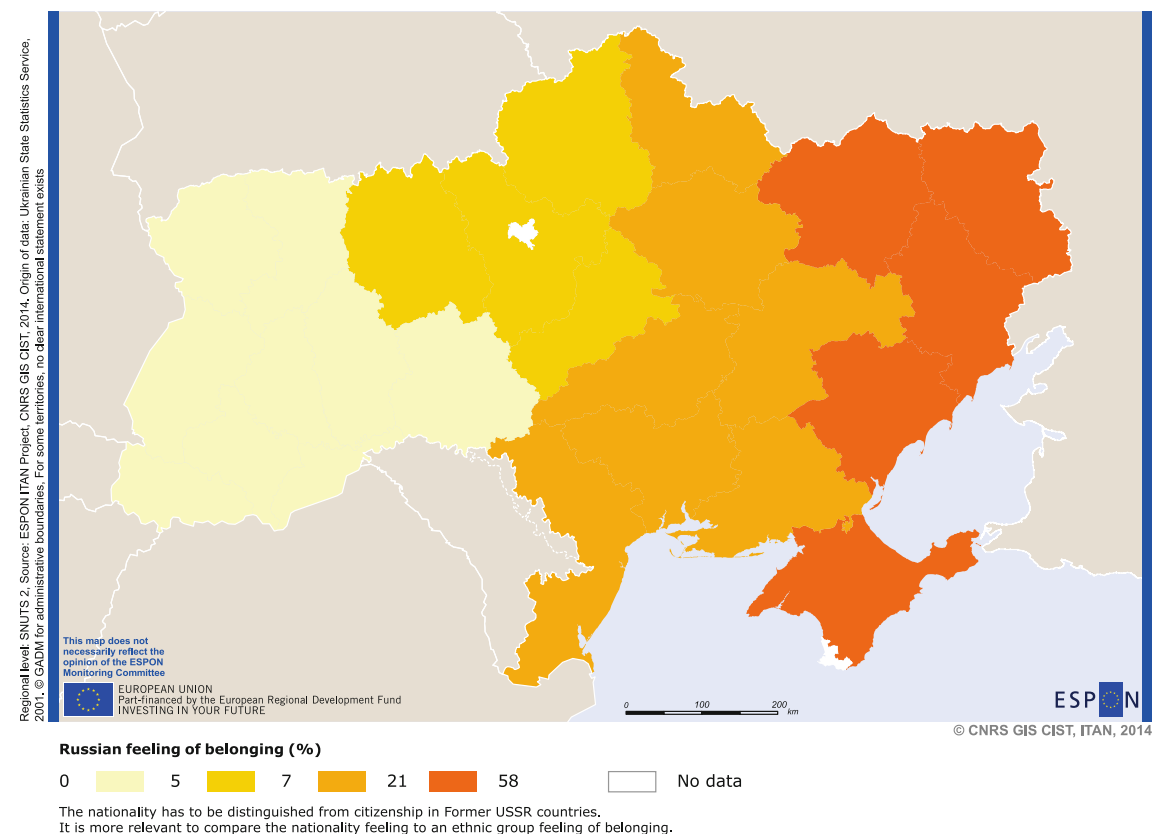

Map 4.11 Russian "belonging feeling", at the beginning of the 2000s. Source Survey elaborated by the State Statistics Service of Ukraine

situation, together with a high ratio of "ethnic" Russians (Map 4.11) and families with a mixed Russian-Ukrainian background, and with the domination of the Russian language in everyday people to people communications, provoked the dissatisfaction of many citizens with the arrival to power in February 2014 of politicians from the West calling for a break with Russia. The joint action of Russian authorities sealed the deepening of the Ukrainian nation-building crisis.

\subsection{Strategic Synthesis: Role of Territorial Cooperation, Key Russia and Energy Issues}

Among the important topics for cooperation between the EU and its eastern neighbours is tackling the environmental challenges of the Baltic Sea. As the Baltic Sea itself is a special eco-system, one that is highly threatened by several environmental hazards, it is vital that all countries around the sea, including those located in the catchment area (Belarus), participate in order to combat the 
consequences of trans-boundary pollution and preserve the sea as a common resource. This topic is currently being addressed in the EU Strategy for the Baltic Sea Region.

The factors that are worsening the degree of territorial integration between the EU and the Eastern neighbourhood include underdeveloped physical infrastructure connecting the East and the West, disparities in access to ICT between the countries (although the disparities are shrinking rather quickly), governance differences (i.e. the room for manoeuvre that regions have to cooperate independently of central government), as well as institutional and organizational bottlenecks (e.g. long border crossing time into the Schengen zone). Due to inefficient procedures, long queues of lorries at crossing points from Finland, Estonia and Latvia have been usual. Simplifying the customs legislation and border crossing procedures and coordinating the development of transport axes between the Eastern neighbourhood and the EU territory would help to avoid similar problems. Development of some large scale transport projects (Via/Rail Baltica-IX transport corridor, and Via Hanseatica) are expected to play an important role in increasing the accessibility of the eastern part of the Baltic Sea. However, their role in the railway connections with Russia and Belarus will be limited by the use of standard European gauge.

Another worsening factor is the deteriorating relationship between the EU and Russia. Given the remaining ties-cultural, economic, political, diplomatic-between Russia and the EU's eastern neighbours, any renewal of the EU's eastern partnership will rely on an improved strategic relationship with Russia.

Russia is the EU's biggest neighbour and third biggest trading partner, and a key supplier of oil and gas to EU member states. In 2013, the share of EU in Russia's foreign trade accounted for $56 \%$. But this share is declining because the turnover with other countries_-primarily, China, but also Turkey and South Korea, etc.-is growing faster: China became Russia's main foreign trade partner instead of Germany. From the perspective of the geographical distribution of FDI, Russia also remains much closer to Europe than to other regions of the world: EU countries account for three quarters of accumulated FDI. Moreover, in the 2000s the EU share was growing-yet investments from Cyprus consist in fact of a repatriation of Russian capital.

When it comes to tourism, the number of Russian citizens visiting foreign countries before the crisis was rapidly increasing. Though their main destinations were the countries of so called cheap tourism (Turkey and Egypt), EU countries also profited of the growing number of Russian tourists, in particular Greece and Finland (the third major destination in 2013), Spain, Germany and Italy. At the same time, the growth of foreign tourism in Russia was modest because of the lack of an adequate infrastructure and because of an unfavourable image of the country. Lastly, West Europe is the main destination of regular flights from/to Russia.

When it comes to territorial development strategies on a macro-regional level, the major ones are VASAB Long-Term Perspective for the Territorial Development of the Baltic Sea Region and the EU Strategy for the Baltic Sea Region (EUSBSR). 
Likewise, the EU Strategy for the Danube Region also brings together both EU states and countries in the Eastern neighbourhood around use of the Danube as a common resource. Russia has also shown interest in macro-regional strategic planning. In 2011 Russia adopted the Strategy on social and economic development of the North-West Federal District (NWFD) until 2020, which also aims at planning large macro-regional units. Today, Russia is involved in the implementation of the Action Plan of the Strategy via the Northern Dimension and, to some extent, via the activities of the Council of The Baltic Sea States and VASAB, but this is insufficient: the exclusion of Russia in the developing process of the EUSBSR is a significant deficit of the Strategy and a step back in the integration process.

Among the good practices of territorial development strategies is the introduction of a bilateral local border traffic agreement between northern Poland and Kaliningrad in 2012, which facilitated the crossing of the Polish-Russian border by residents of the entire Kaliningrad region. This agreement is seen as an important step towards creating a legal basis facilitating movement of people between the two countries. It plays an important role in facilitating direct social, cultural, tourist and other people-to-people contacts, which is a precondition for increased regional integration. The countries also established a regular cooperation in fighting international organized crime and border security.

In the case of sector specific cooperation, the bilateral relationship between the eastern Finland and the Republic of Karelia in Russia in the forestry sector can be emphasized as a good example of a well-functioning cross-border partnership.

As to other relevant actors outside the international policy arena, the development of closer ties is supported by regional authorities, business actors, NGOs and academia. The Baltic University Programme (BUP) can be highlighted as a unique regional university network with about 225 universities in the 14 countries across the Baltic Sea region, including Belarus, Russia and Ukraine. Among the findings of the ESPON "TERCO" project was that the probability of successful territorial cooperation with more tangible outcomes is higher if NGOs and local and regional governments, rather than national governments, initiate the cooperation (Euroreg 2012).

However, due to the Ukrainian crisis, the changing geopolitical atmosphere is expected to cause a change in the quality of relations between the EU and the Eastern neighbourhood and lead to their deterioration. The Ukrainian crisis reveals major stakes on a higher scale: Western Ukraine is increasing its orientation to the EU, whereas Russia is strengthening its economic ties with Asian and Central Asian countries. In the current situation energy issues become in the centre of attention once again. A European Energy policy is an indispensable prerequisite for a genuine partnership between the EU member states and Russia, instead of the current dispersed member states' gas agreements with Russia, though Russian and even a number of Western experts express justified objections against its implementation. This is the overarching condition for better cooperation on all scales between the EU and the Eastern neighbours (Fig. 4.2). 


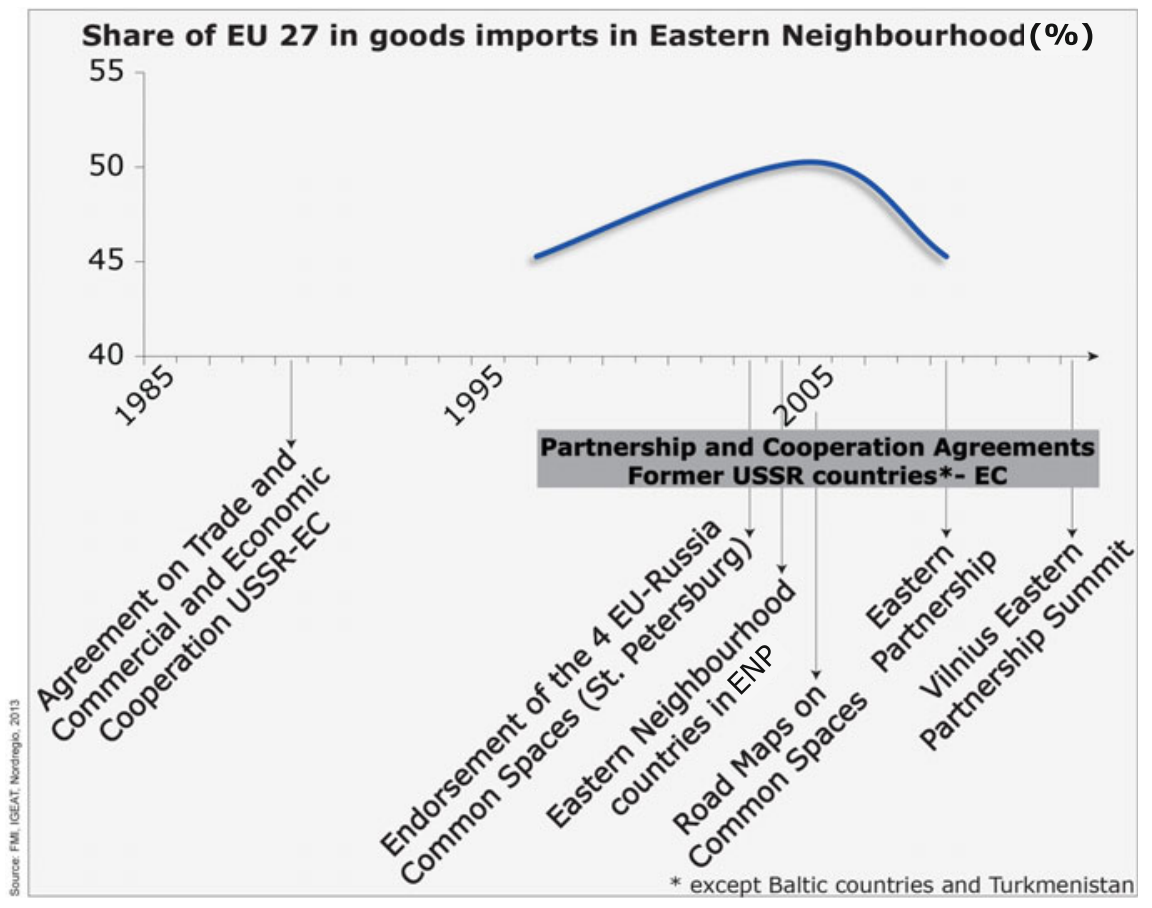

Fig. 4.2 Agreements $v$. real integration with the EU—Eastern neighbourhood

Open Access This chapter is distributed under the terms of the Creative Commons AttributionNoncommercial 2.5 License (http://creativecommons.org/licenses/by-nc/2.5/) which permits any noncommercial use, distribution, and reproduction in any medium, provided the original author(s) and source are credited. The images or other third party material in this chapter are included in the work's Creative Commons license, unless indicated otherwise in the credit line; if such material is not included in the work's Creative Commons license and the respective action is not permitted by statutory regulation, users will need to obtain permission from the license holder to duplicate, adapt or reproduce the material.

\section{References}

Böhme, K. 2013. Added value of macro regional strategies: a governance perspective. Spatial Foresight Brief 2013:3. http://www.spatialforesight.eu/tl_files/files/editors/dokumente/Brief2013-3-130710.pdf.

BSR. 2012. The BSR in the focus of development strategies of the EU and the Russian Federation. http://www.bsr2012.eu/wp-content/uploads/Russia-EU-BSR-Development-Strategies.pdf.

EC. 2013. Concerning the added value of macro-regional strategies", $\operatorname{COM(2013)~} 468$ final. Available at: http://ec.europa.eu/regional_policy/sources/docoffic/official/communic/baltic/ com_added_value_macro_region_strategy_en.pdf. 
ENPI. 2007. European neighbourhood and partnership instrument. Eastern Regional Programme Strategy Paper 2007-2013. Available at: http://ec.europa.eu/world/enp/pdf/country/enpi_ eastern_rsp_en.pdf.

ENVSEC. 2006. Identification and review of key environment and security problems in the Republic of Moldova. Background paper for UNEP.

ENVSEC. 2010. http://envsec.grid.unep.ch/easteur/index.php.

Euroreg. 2012. TERCO-European Territorial Co-operation as a factor of growth, jobs and quality of life. ESPON project, Applied Research 2013/1/9.

Henry, L.A., and V. Douhovnikoff. 2008. Environmental issues in Russia. Annual Review of Environnment. Available at: http://www.bowdoin.info/faculty/v/vdouhovn/pdf/douhovnikoffenvironmental-issues-in-russia.pdf.

Kuznetsov. 2012. Transborder corporate integration in the Baltic Sea Region", Institute of World Economy and International Relations (IMEMO). Available at: http://mpra.ub.uni-muenchen. de/43736/1/MPRA_paper_43736.pdf.

Kvasha, E.A., and T.L. Harjkova. 2010. Life expectancy of the adult population in the regions of Russia during the last decade. Ожидаемая продолжительность жизни взрослого населения в регионах России в последнее десятилетие. Available at: http://publications.hse.ru/articles/ 68853238.

Lagutov, V. 2011. Environmental security in watersheds: the Sea of Azov. NATO Science for Peace and Security Series-C: Environmental Security. Available at: http://books.google.se/ books?id=xQCUGWs- 8 HEC $\& \mathrm{dq}=$ the + sea + of + Azov+environmental + threats $\&$ hl $=$ sv $\&$ source $=$ gbs_navlinks_s.

Nordregio. 2012. "ET2050", Baltic Sea region \& Nordic and Northern Peripheries region report, Stockholm.

Richard, Y., A. Sebentsov, and M. Zotova. 2015. The Russian exclave of Kaliningrad. Challenges and limits of its integration in the Baltic region. Cybergeo: European Journal of Geography [on line], Espace, Société, Territoire, document 719, http://cybergeo.revues.org/26945.

Rogoża, J., A. Wierzbowska-Miazga, and I. Wiśniewska. 2012. A Captive Island-Kaliningrad between Moscow and the EU. Warszawa: OSW Studies, Centre for Eastern Studies.

Ross, C., and A. Campbell. 2008. Federalism and local politics in Russia. Oxford: BASEES/ Routledge Series on Russian and East European Studies.

Sebentsov A.B., and M.B. Zotova. 2013. Себенцов А.Б; Зотова М.В “Российский эксклав на Балтике: потенциал ЭГП и возможности его реализации.

State of the Region Report. 2012. Baltic development forum. http://www.bdforum.org/cmsystem/ wp-content/uploads/BDF_SoRR_2012_10.pdf.

Teurtrie, D. 2012. Union Européenne ou Russie: le dilemme ukrainien », Outre-Terre, 2, 347-353, Le Bouscat.

Zimin, D., 2013, Russia's oil and gas export infrastructure. New routes, new actors. In The EU-Russia corderland, new contexts for regional co-operation. Oxford: Routledge. 